\title{
Axial Map を用いた伝統的建造物保存地区の 空間位相的接続性の分析に関する研究

\author{
A STUDY ON THE TOPOLOGICAL CONNECTIVITY OF PRESERVATION DISTRICTS \\ FOR GROUPS OF TRADITIONAL BUILDINGS BY USING THE AXIAL MAP
}

\author{
劉澤*, 趙 世 晨**
}

Ze LIU and Shichen ZHAO

\begin{abstract}
In this research, we selected 40 Preservation Districts for Groups of Traditional Buildings in Japanese urban area as objects. We aimed to quantitatively analyze the surrounding area which would affect the space connectivity of Preservation Districts significantly. By using Space Syntax Theory, we analyzed the connective relationship between Preservation Districts and surrounding area ranging 2,000 meters. These 40 objectives could be classified into 5 types. We divided the surrounding area into a series of ranges. We found the characteristics of connectivity of Preservation Districts and the main ranges of effect by analyzing the contribution ratio of connectivity value.
\end{abstract}

Keywords : Preservation Districts for Groups of Traditional Buildings, Street Space, Space Syntax Theory, Topological Connectivity 重要伝統的建造物群保存地区, 街路空間, スペースシンタックス理論, 位相的接続性

\section{1. はじめに}

\section{1 研究の背景}

日本の歴史的都市において、旧来のみちすじ、街路が昔のままで 引き継がれている場合が多く、今でも各都市の市街地の骨格になっ ている。それらの歴史的みちすじは、都市内の交通を相互に補完し 合い、共同的に地域の特徵がある歴史的道路網の形態を構築してい る。一方、1975 年に重要伝統的建造物保存地区（以下：重伝建地区） 制度の創設により、面的かつ総合的に歴史的地区に対するまちづく りが展開され、地区内の歴史的道路網は景観創出や地域個性形成の 要素として重視されてきた。さらに、1982 年より「歴史的地区環境 整備街路事業（通称、歴夕ち事業）」が創設されて以来、重伝建地区 の街並み環境の保存及びみちすじの整備等の動きは、各都市で見ら れる。

このような状況の中で、旧来のみちすじによって形成された道路 網、特に重伝建地区においては、都市道路網の整備と歴史的地区の 保全に矛盾が生じないように、対策を取るべきである。それゆえ、 重伝建地区の道路網の構造的特徵に着目し、重伝建地区とその周辺 地区の道路網との空間的関係を定量的に把握することは、きわめて 重要であると考える。

\section{2 研究目的と論文構成}

前述の背景を踏まえて、本研究では、歴史的街路整備事業が行わ れている伝統的建造物保存地区に注目し、都市街路網における保存
地区内と周辺都市空間の位相的つながり（以下：接続性注 ${ }^{1}$ ）に焦点 を当て、道路ネットワークの数理的解析を行うことによって、重伝 建地区と周辺道路網の接続関係を定量的に把握し、さらに周辺地区 が重伝建地区の接続性に与えている影響を明らかにすることを目的 としている。

本論文は 5 節で構成されている。第 1 節では、本研究の背景と目的、 既往研究について述べている。第 2 節では、研究対象の選定方法及 び解析手法と各指標の概要について述べている。第 3 節では、接続 性の観点から、各重伝建地区の現状を把握した上で、その周辺 $2,000 \mathrm{~m}$ エリアにおける各地区の接続関係を明らかにする。第 4 節では、周

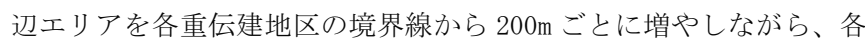
地区における接続性の変化傾向を解明し、さらに、周辺地区が重伝 建地区の接続性に与えている影響及びその範囲区間を明らかにする。 第 5 節では、本研究の結果を要約し、まとめとする。

\section{3 既往研究}

既往研究では、重伝建地区の街路空間に関する研究は数多く行わ れている。まず、重伝建地区の指定範囲内に着目している研究では、 中村ら ${ }^{1)}$ が伝建地区における街路舗装の問題点を意識したアンケー トや現地調查を行い、街路整備の実態と課題を明らかにしている。 松本ら ${ }^{2)}$ は、美濃加茂市太田宿地区を対象に、伝統的街路の景観要 素の評価方法を検討し、重伝建地区における景観整備と街路空間構 成の関係について考察を行っている。菊地ら ${ }^{3)}$ は、筑後吉井重伝建
$*$ 九州大学大学院人間環境学府 博士後期課程

** 九州大学大学院人間環境学研究院 准教授·博士 (工学)
Grad. Stud., Graduate School of Human-Environment Studies, Kyushu Univ., M. Env. Assoc. Prof., Faculty of Human-Environment Studies, Kyushu Univ., Dr. Eng. 
地区を事例に土地利用の実態を追跡調查し、重伝建地区の整備が沿 道の産業構成に及ぼす影響を明らかにしている。長谷見ら ${ }^{4)}$ は、奈 良井・木曾平沢を事例とし、街路の構成と防災設備の分布状況から、 歴史町並夕保存の防災計画の手法と問題点について考察を行ってい る。また、重伝建地区の指定範囲より広い街路空間を扱った研究に 関して、観光者の行動の側面から伝建地区における街路の回遊性及 び観光者の移動範囲を定性的に論述した窪田ら ${ }^{5), 6)}$ の一連の研究が ある。

本研究は、これらの既往研究の成果を踏まえながら、重伝建地区 における街路空間の特徴を把握し、街路整備事業に基礎情報を提供 するために、重伝建地区とその周辺地区との空間的関係に着目し、 空間の接続性を明らかにすると同時に、周辺地区が重伝建地区に与 える影響を明らかにしようとするものである。

\section{2. 研究の対象と方法}

\section{1 研究対象と範囲の設定}

本研究では、重伝建地区の歴史的街路空間とそれに隣接している 街路空間との関係性に重点をおいて、国が選定した重伝建地区の 104 ヶ所（2013 年 8 月現在）の中から、以下のことを考慮して 40 地 区（図 1）を選び、本研究の対象とした。1）郡村部、山間部などの 重伝建地区は、主に農山村集落や歷史の産業町（鉱山町、製磁町な ど）で、立地環境などの制約のため、現在の都市域と乘離しており、 市街地の規模も小さいため、周辺地区の街路空間は重伝建地区に与 えている影響も比較的に弱い。そこで、研究結果の妥当性を考慮し、 本研究では、行政単位としての「市」に属している地区、かつ当該 地区は都市部の密集地または主要交通機関、行政機関と隣接してい る地区を選定する。2）条件 1）をもとに、これまでの重伝建地区に 対する整備事業や取り組みなどの実施状沉を考察した上で、都市計 画の道路整備と直接に関連している「歴史的地区環境整備街路事業 (通称、歴みち事業)」や「街なみ環境整備事業」などの代表的な事 業を実施した地区または実施中の地区を抽出し、本研究の分析対象 として選定する。これらの対象地区では、歴史的地区の環境と周辺 の都市道路との調和が重視され、適正な整備計画が策定される必要 があると考えられる。

また、研究対象地区の範囲設定では、1）重伝建地区が含まれること、 2）各対象地区における街路事業の実施現状を考慮し、歴史的街路に 関する整備事業を行っている主な市街地区域及び計画中の区域が含 まれること、3）市街地の規模を考慮し、重伝建地区の周辺、特に主 要交通機関（駅など）や行政機関（市役所など）が含まれること、4） 対象地区間の比較やSpace Syntax 理論を適用する際の計算の効率性 を確保すること、5）既往研究の分析範囲 $\left.{ }^{10)} \sim 12\right)$ などを参照する、と の 5 点に従い、重伝建地区の中心から半径 $2,000 \mathrm{~m}$ のエリアを分析範 囲とした。

\section{2 研究方法}

空間相互接続性の分析方法として、Space Syntax 理論（以下：SS 理論）が知られている。SS 理論は、1980 年代前半、UCL の Hillier らによって提唱・確立され、空間の位相的関係を定量的に解析する 手法として、国際的に注目されている。日本国内でも数多くの既往 研究の中で適用されている。SS 理論の基本概念には、対象空間を抽 象する要素によって、イソビスタ (isovist) から発展した可視領域 (視

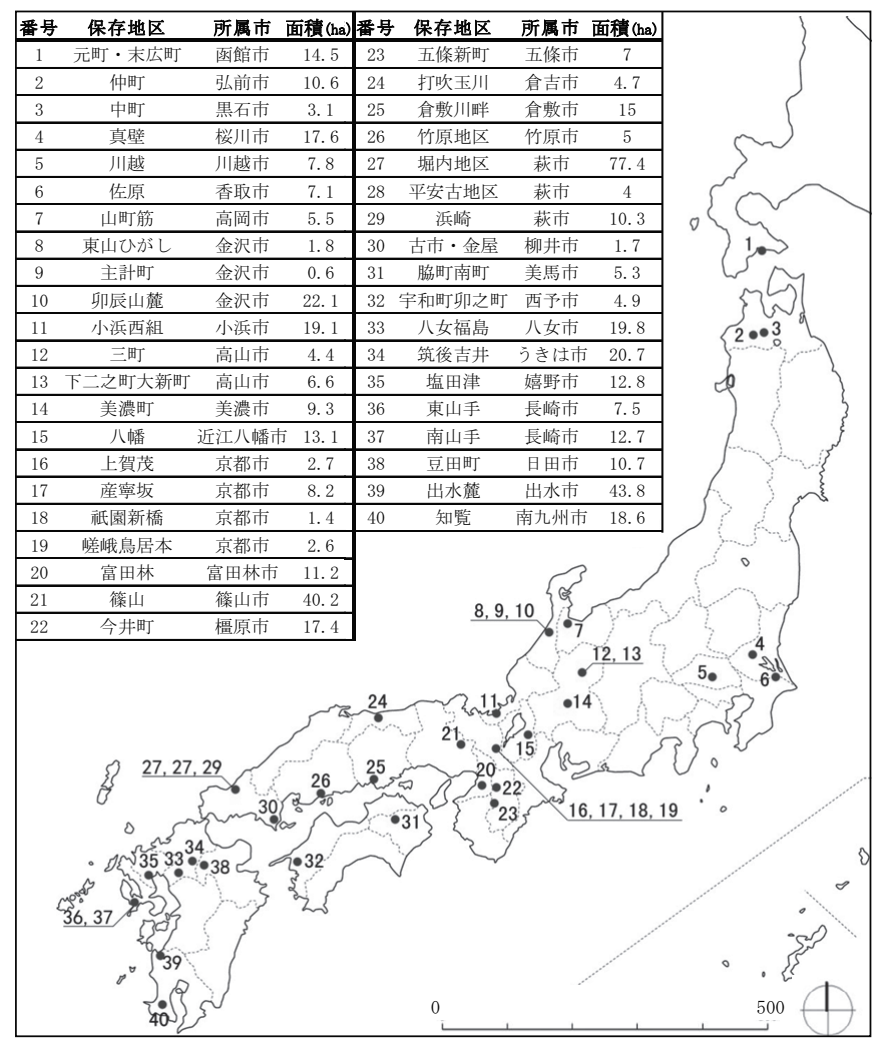

図 1 対象地区の位置

覚的広がり）を解析できるVisibility Graph Analysis (VGA) ${ }^{17), 18)}$ 及び凸空間、軸線に基づくConvex Analysis、Axial Analysis ${ }^{13)}$ な どの解析手法がある。前者は、空間の視認性 ${ }^{19,20)}$ 及び視覚的関係 21),22) の分析を中心した分析方法である。本研究の場合、街路空間 の位相的接続性を明らかにするために、後者の方法に着目した。ま た、分析対象の範囲は約 1,256ha（半径 2000m） と大きく、解析方 法は有機的形状をもつ大規模都市空間の解析に適している Axial

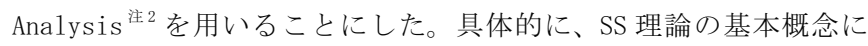
より、街路空間の平面をすべての内角が 180 度未満となる凸空間注 3 （コンベックススペース）に分割し、そして全ての凸空間を貫通する ようにAxial Lineを描いて、Axial Lineの集合体である軸線マッ プを得た。その上で、Depthmap を用い、余分な軸線を刈込み、軸線 マップを精細化したAxial Map 注4 をもとに、Axial Analysis を行っ た。操作手順及び評価指標 ${ }^{7}$ を整理・要約すると図 2 のようになる。 Axial Analysisには、 5 種の指標（式 1 〜式 5）が存在する。この内、 Integration Value(式 4, 以下: Int.V) は、Axial Lineの接続性を 最も直接に表寸指標である。この数值が高いと、あるAxial Line か ら他のすべての Line に対して、位相的移動距離の合計がより少なく なり、移動効率に優れているとされている。この状態は統合された 空間と表現され、空間全体の中心になりやすい。逆に数值が低い場合、 位相距離は離れており、分離された空間と表現される。また、Int. $\mathrm{V}$ の值は標準化された指標で、道路本数や地区規模の異なる研究対 象においても解析結果の比較は可能であり、本研究の分析に適して いる。ここで、各重伝建地区の接続性を総合的に把握する指標とし て、各重伝建地区におけるAxial Lineの Int.V 平均値（式 5）を用 いた。分析の際に、まず、距離によって限定された解析範囲 $(2,000 \mathrm{~m}$ 及び第 4 章の $200 \mathrm{~m} \sim 1,600 \mathrm{~m})$ ごとに、Axial Map をそれぞれ作成し 
た。次に、重伝建地区においては、街路空間 は交差点から次の交差点までの区間リンクを 単位として代表点を設けた。そして各代表点 のInt. V を集計し、その平均值を求めた。な お、一つの区間リンクに複数の Axial Line が 重なっている場合、複数 Axial Line の Int. V の平均を代表点の Int. V とした。SS 理論にお いては、Int.V の平均值が高くなればなるほじ、 地区の浸透率 (Permeability) も高いとされ ており、当該地区における移動効率が優位で あると意味する。

\section{3 解析レベルの設定}

SS 理論において、Axial Line 同士の距離は、 その間に介在する Lineの数（Depth）という 位相幾何学的尺度で表されている。従って、 Depthの設定によって、同一空間の Int.Vが異 なる場合がある。その中、Depthの上限を設定 せず、全領域を対象とした場合は Global (Rn) レベル（図2の右欄に示す)、Depthの数 （Radius）を任意の数值に設定して解析する場 合はLocal レベル (図 2 の左欄に示す) という。 本研究では、周辺エリアの街路空間全体が重伝 建地区の接続性に与えている影響に着目して いるために、解析のレベルとして Global (Rn) が適している。

\section{3. 空間接続性の解析結果}

\section{1 Int. V 平均値による総合的評価}

まず、重伝建地区内における街路空間の接 続性を見るために、先述の解析方法を用い、 各代表点の Int.V を算出した。図 3 にしめす ように、40 対象地区の Int.Vの平均值（表 1 の左欄の「地区内」）では、20. 富田林 (2.273) は他の地区に比べて非常に高い值を示した。 つまり、重伝建地区内のみに着目した場合、 この地区の街路空間の接続性が最も良く、地 区内部の移動効率が優れているといえる。

次に、周辺地区の影響を考慮して重伝建地 区の空間接続性を見るために、Depth をRn と し、対象地区の Global レベルにおいて、Int. $\mathrm{V}$ の值を算出した後、重伝建地区内の平均值 (表 1 の左欄の「Rn」に示す) を求めた。表 1 に示 すように、3. 中町 (1.714)、7. 山町筋 (1.653)、5. 川越 (1.542)、1. 元 町・末広町 (1.435) が比較的高い值になっている。先の重伝建地区 内の計算結果に比べると、Int. V の平均值は下がっており、また最大 值となっている地区も異なっていることから、これは周辺地区が重 伝建地区に対して影響を与えていることを示唆している。

\section{2 周辺地区との接続関係}

ここで、重伝建地区を中心に2,000m の周辺エリア (Depth 範囲= Rn）において、重伝建地区とその周辺地区との空間的接続性の相対

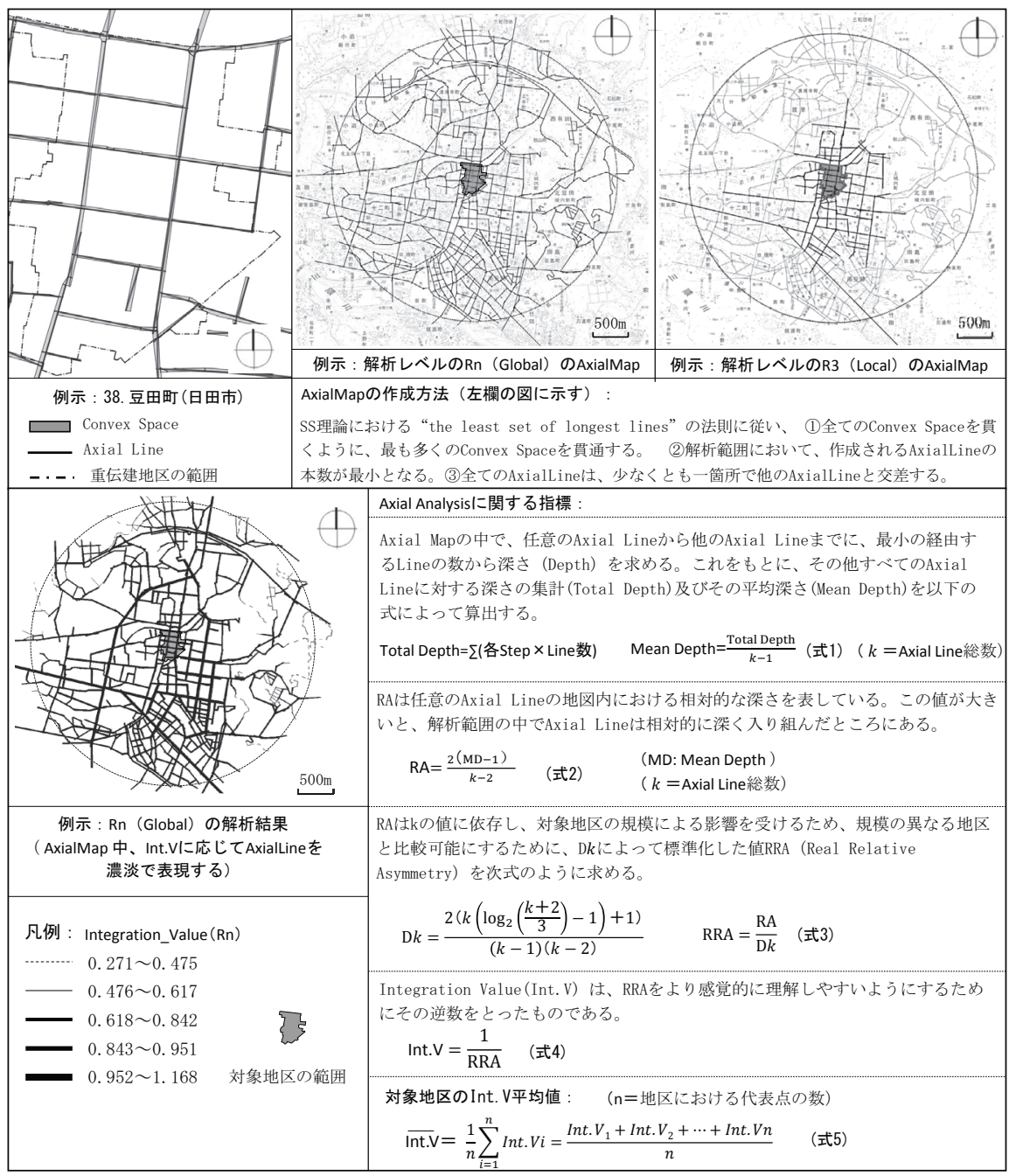

図 2 SS 理論に関する分析手順及び評価指標

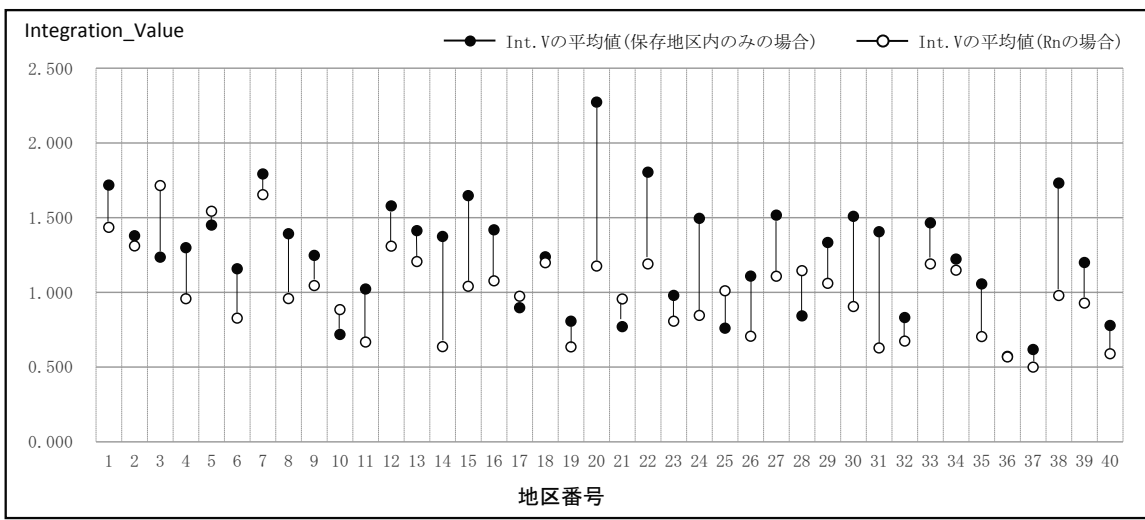

図 3 各対象地区における Int. V の平均值

関係を明らかにする。まず、各重伝建地区を中心に $2,000 \mathrm{~m}$ 周辺地 区の全体を解析範囲とし、それぞれの Axial Line の Int. V を算出し た。次に、その值を 5 段階に分けて、各段階に占める重伝建地区内 の街路空間の構成比を求め、その結果を表 1 の右欄に示す。段階 1 における街路空間は、2,000m 範囲全体の Int. V に占める割合が上位 の $20 \%$ となっており、 5 段階の中で移動効率が最も優れている。こ れに対して、段階 5 における街路空間の Int. V は、範囲全体に占め る割合が下位の $20 \%$ となっており、接続性の相対的劣位にある。 
表 1 各対象地区における街路空間の Int. V の構成比

\begin{tabular}{|c|c|c|c|c|c|c|c|c|c|c|c|c|c|c|c|}
\hline \multirow{3}{*}{ 番号 } & \multirow{3}{*}{ 名称 } & \multirow{3}{*}{$\begin{array}{l}\text { 性格 } \\
\text { 種別 }\end{array}$} & \multicolumn{2}{|c|}{ Int. Vの平均値 } & \multicolumn{11}{|c|}{ 重伝建地区内及び領域全体に占める構成比 } \\
\hline & & & \multirow{2}{*}{ 地区内 } & \multirow{2}{*}{$\mathrm{Rn}$} & \multirow{2}{*}{ 類型 } & \multicolumn{2}{|c|}{ 段階 1} & \multicolumn{2}{|c|}{ 段階 2} & \multicolumn{2}{|c|}{ 段階 3} & \multicolumn{2}{|c|}{ 段階 4} & \multicolumn{2}{|c|}{ 段階 5} \\
\hline & & & & & & 地区内部 & 範囲全体 & 地区内部 & 範囲全体 & 地区内部 & 範囲全体 & 地区内部 & 範囲全体 & 地区内部 & 範囲全体 \\
\hline 3 & 中町 & 商家町 & 1.235 & 1.714 & & $90.8 \%$ & $5.0 \%$ & $9.2 \%$ & $0.9 \%$ & $0.0 \%$ & $0.0 \%$ & $0.0 \%$ & $0.0 \%$ & $0.0 \%$ & $0.0 \%$ \\
\hline 14 & 美濃町 & 商家町 & 1.373 & 0.636 & 中心刑 & $92.3 \%$ & $14.8 \%$ & $7.7 \%$ & $0.4 \%$ & $0.0 \%$ & $0.0 \%$ & $0.0 \%$ & $0.0 \%$ & $0.0 \%$ & $0.0 \%$ \\
\hline 31 & 脇町南町 & 商家町 & 1.405 & 0.627 & 中心㚙 & $93.3 \%$ & $10.7 \%$ & $6.7 \%$ & $0.4 \%$ & $0.0 \%$ & $0.0 \%$ & $0.0 \%$ & $0.0 \%$ & $0.0 \%$ & $0.0 \%$ \\
\hline 35 & 塩田津 & 商家町 & 1.056 & 0.704 & & $91.9 \%$ & $16.5 \%$ & $8.1 \%$ & $3.4 \%$ & $0.0 \%$ & $0.0 \%$ & $0.0 \%$ & $0.0 \%$ & $0.0 \%$ & $0.0 \%$ \\
\hline 1 & 元町・末広町 & 港町 & 1.718 & 1.435 & & $31.3 \%$ & $33.3 \%$ & $34.4 \%$ & $9.0 \%$ & $34.4 \%$ & $4.8 \%$ & $0.0 \%$ & $0.0 \%$ & $0.0 \%$ & $0.0 \%$ \\
\hline 2 & 仲町 & 武家町 & 1.378 & 1.310 & & $23.8 \%$ & $33.8 \%$ & $23.8 \%$ & $4.0 \%$ & $52.4 \%$ & $3.4 \%$ & $0.0 \%$ & $0.0 \%$ & $0.0 \%$ & $0.0 \%$ \\
\hline 5 & 川越 & 商家町 & 1.450 & 1.542 & 均衡型 & $23.1 \%$ & $29.4 \%$ & $53.8 \%$ & $7.4 \%$ & $23.1 \%$ & $1.0 \%$ & $0.0 \%$ & $0.0 \%$ & $0.0 \%$ & $0.0 \%$ \\
\hline 7 & 山町筋 & 商家町 & 1.792 & 1.653 & & $25.0 \%$ & $42.9 \%$ & $58.3 \%$ & $12.1 \%$ & $16.7 \%$ & $1.0 \%$ & $0.0 \%$ & $0.0 \%$ & $0.0 \%$ & $0.0 \%$ \\
\hline 34 & 筑後吉井 & 在郷町 & 1.222 & 1.148 & & $24.2 \%$ & $53.6 \%$ & $46.8 \%$ & $19.7 \%$ & $27.4 \%$ & $6.1 \%$ & $1.6 \%$ & $0.5 \%$ & $0.0 \%$ & $0.0 \%$ \\
\hline 4 & 真壁 & 在郷町 & 1.298 & 0.957 & & $8.0 \%$ & $5.7 \%$ & $92.0 \%$ & $14.5 \%$ & $0.0 \%$ & $0.0 \%$ & $0.0 \%$ & $0.0 \%$ & $0.0 \%$ & $0.0 \%$ \\
\hline 6 & 佐原 & 商家町 & 1.157 & 0.827 & & $23.8 \%$ & $10.0 \%$ & $76.2 \%$ & $7.3 \%$ & $0.0 \%$ & $0.0 \%$ & $0.0 \%$ & $0.0 \%$ & $0.0 \%$ & $0.0 \%$ \\
\hline 9 & 主計町 & 茶屋町 & 1.247 & 1.045 & & $12.5 \%$ & $1.4 \%$ & $62.5 \%$ & $1.1 \%$ & $25.0 \%$ & $0.3 \%$ & $0.0 \%$ & $0.0 \%$ & $0.0 \%$ & $0.0 \%$ \\
\hline 12 & 三町 & 商家町 & 1.578 & 1.308 & & $44.4 \%$ & $7.5 \%$ & $55.6 \%$ & $2.3 \%$ & $0.0 \%$ & $0.0 \%$ & $0.0 \%$ & $0.0 \%$ & $0.0 \%$ & $0.0 \%$ \\
\hline 13 & 下二之町大新町 & 商家町 & 1.412 & 1.206 & & $25.0 \%$ & $7.5 \%$ & $68.8 \%$ & $5.0 \%$ & $6.3 \%$ & $0.4 \%$ & $0.0 \%$ & $0.0 \%$ & $0.0 \%$ & $0.0 \%$ \\
\hline 20 & 富田林 & 在郷町 & 2.273 & 1.175 & 近隣 & $10.0 \%$ & $6.3 \%$ & $85.0 \%$ & $7.3 \%$ & $5.0 \%$ & $0.3 \%$ & $0.0 \%$ & $0.0 \%$ & $0.0 \%$ & $0.0 \%$ \\
\hline 24 & 打吹玉川 & 商家町 & 1.494 & 0.845 & 中心型 & $35.5 \%$ & $13.4 \%$ & $64.5 \%$ & $11.4 \%$ & $0.0 \%$ & $0.0 \%$ & $0.0 \%$ & $0.0 \%$ & $0.0 \%$ & $0.0 \%$ \\
\hline 30 & 柳井 & 商家町 & 1.508 & 0.905 & & $45.5 \%$ & $6.9 \%$ & $54.5 \%$ & $3.2 \%$ & $0.0 \%$ & $0.0 \%$ & $0.0 \%$ & $0.0 \%$ & $0.0 \%$ & $0.0 \%$ \\
\hline 32 & 宇和町卯之町 & 在郷町 & 0.831 & 0.673 & & $38.9 \%$ & $10.8 \%$ & $50.0 \%$ & $5.4 \%$ & $11.1 \%$ & $1.0 \%$ & $0.0 \%$ & $0.0 \%$ & $0.0 \%$ & $0.0 \%$ \\
\hline 33 & 八女福島 & 商家町 & 1.464 & 1.190 & & $14.3 \%$ & $15.6 \%$ & $83.7 \%$ & $16.8 \%$ & $2.0 \%$ & $0.3 \%$ & $0.0 \%$ & $0.0 \%$ & $0.0 \%$ & $0.0 \%$ \\
\hline 38 & 豆田町 & 商家町 & 1.731 & 0.979 & & $33.3 \%$ & $9.1 \%$ & $66.7 \%$ & $4.8 \%$ & $0.0 \%$ & $0.0 \%$ & $0.0 \%$ & $0.0 \%$ & $0.0 \%$ & $0.0 \%$ \\
\hline 40 & 知覧 & 武家町 & 0.778 & 0.588 & & $52.4 \%$ & $12.9 \%$ & $47.6 \%$ & $4.4 \%$ & $0.0 \%$ & $0.0 \%$ & $0.0 \%$ & $0.0 \%$ & $0.0 \%$ & $0.0 \%$ \\
\hline 8 & 東山ひがし & 茶屋町 & 1.391 & 0.958 & & $0.0 \%$ & $0.0 \%$ & $42.9 \%$ & $2.5 \%$ & $57.1 \%$ & $2.6 \%$ & $0.0 \%$ & $0.0 \%$ & $0.0 \%$ & $0.0 \%$ \\
\hline 11 & 小浜西組 & 茶屋町 & 1.022 & 0.667 & & $16.7 \%$ & $5.8 \%$ & $63.9 \%$ & $13.9 \%$ & $22.2 \%$ & $7.0 \%$ & $0.0 \%$ & $0.0 \%$ & $0.0 \%$ & $0.0 \%$ \\
\hline 15 & 八幡 & 商家町 & 1.647 & 1.040 & & $6.3 \%$ & $9.1 \%$ & $62.5 \%$ & $8.8 \%$ & $31.3 \%$ & $2.7 \%$ & $0.0 \%$ & $0.0 \%$ & $0.0 \%$ & $0.0 \%$ \\
\hline 18 & 祇園新橋 & 茶屋町 & 1.237 & 1.198 & & $0.0 \%$ & $0.0 \%$ & $11.1 \%$ & $0.5 \%$ & $88.9 \%$ & $3.0 \%$ & $0.0 \%$ & $0.0 \%$ & $0.0 \%$ & $0.0 \%$ \\
\hline 19 & 嵯峨鳥居本 & 門前町 & 0.806 & 0.635 & & $15.0 \%$ & $8.6 \%$ & $50.0 \%$ & $6.8 \%$ & $35.0 \%$ & $5.3 \%$ & $0.0 \%$ & $0.0 \%$ & $0.0 \%$ & $0.0 \%$ \\
\hline 21 & 篠山 & 城下町 & 0.770 & 0.955 & & $12.1 \%$ & $18.9 \%$ & $39.7 \%$ & $11.4 \%$ & $43.1 \%$ & $8.3 \%$ & $5.2 \%$ & $1.4 \%$ & $0.0 \%$ & $0.0 \%$ \\
\hline 22 & 今井町 & 寺内町 & 1.804 & 1.320 & & $2.6 \%$ & $7.1 \%$ & $48.7 \%$ & $9.2 \%$ & $48.7 \%$ & $5.0 \%$ & $0.0 \%$ & $0.0 \%$ & $0.0 \%$ & $0.0 \%$ \\
\hline 23 & 五條新町 & 商家町 & 0.979 & 0.806 & 偏心㔖 & $3.0 \%$ & $5.9 \%$ & $57.6 \%$ & $21.0 \%$ & $39.4 \%$ & $7.4 \%$ & $0.0 \%$ & $0.0 \%$ & $0.0 \%$ & $0.0 \%$ \\
\hline 26 & 竹原地区 & 製塩町 & 1.108 & 0.706 & & $12.5 \%$ & $5.5 \%$ & $66.7 \%$ & $15.4 \%$ & $20.8 \%$ & $4.2 \%$ & $0.0 \%$ & $0.0 \%$ & $0.0 \%$ & $0.0 \%$ \\
\hline 27 & 堀内地区 & 武家町 & 1.516 & 1.107 & & $0.0 \%$ & $0.0 \%$ & $22.9 \%$ & $5.4 \%$ & $65.7 \%$ & $11.6 \%$ & $11.4 \%$ & $2.5 \%$ & $0.0 \%$ & $0.0 \%$ \\
\hline 28 & 平安古地区 & 武家町 & 0.842 & 1.144 & & $0.0 \%$ & $0.0 \%$ & $37.5 \%$ & $2.0 \%$ & $62.5 \%$ & $2.5 \%$ & $0.0 \%$ & $0.0 \%$ & $0.0 \%$ & $0.0 \%$ \\
\hline 36 & 東山手 & 港町 & 0.571 & 0.567 & & $4.9 \%$ & $2.0 \%$ & $39.0 \%$ & $7.2 \%$ & $78.0 \%$ & $9.9 \%$ & $0.0 \%$ & $0.0 \%$ & $0.0 \%$ & $0.0 \%$ \\
\hline 37 & 南山手 & 港町 & 0.617 & 0.499 & & $19.6 \%$ & $19.0 \%$ & $17.5 \%$ & $17.4 \%$ & $62.9 \%$ & $5.3 \%$ & $0.0 \%$ & $0.0 \%$ & $0.0 \%$ & $0.0 \%$ \\
\hline 39 & 出水麓 & 武家町 & 1.199 & 0.927 & & $11.9 \%$ & $13.3 \%$ & $30.3 \%$ & $22.4 \%$ & $57.8 \%$ & $11.8 \%$ & $0.0 \%$ & $0.0 \%$ & $0.0 \%$ & $0.0 \%$ \\
\hline 10 & 卯辰山麓 & 寺町 & 0.718 & 0.884 & & $6.4 \%$ & $9.7 \%$ & $25.5 \%$ & $5.9 \%$ & $50.9 \%$ & $9.0 \%$ & $16.4 \%$ & $9.0 \%$ & $0.0 \%$ & $0.0 \%$ \\
\hline 16 & 上賀茂 & 社家町 & 1.418 & 1.077 & & $0.0 \%$ & $0.0 \%$ & $0.0 \%$ & $0.0 \%$ & $60.0 \%$ & $1.9 \%$ & $40.0 \%$ & $2.5 \%$ & $0.0 \%$ & $0.0 \%$ \\
\hline 17 & 産寧坂 & 門前町 & 0.896 & 0.973 & 乘離型 & $0.0 \%$ & $0.0 \%$ & $2.3 \%$ & $0.5 \%$ & $27.9 \%$ & $4.5 \%$ & $55.8 \%$ & $16.6 \%$ & $14.0 \%$ & $3.4 \%$ \\
\hline 25 & 倉敷 & 商家町 & 0.760 & 1.010 & & $0.0 \%$ & $0.0 \%$ & $17.1 \%$ & $4.5 \%$ & $47.1 \%$ & $7.1 \%$ & $35.7 \%$ & $13.1 \%$ & $0.0 \%$ & $0.0 \%$ \\
\hline 29 & 浜崎 & 港町 & 1.333 & 1.060 & & $2.6 \%$ & $6.7 \%$ & $10.5 \%$ & $2.7 \%$ & $63.2 \%$ & $12.1 \%$ & $23.7 \%$ & $5.7 \%$ & $0.0 \%$ & $0.0 \%$ \\
\hline
\end{tabular}

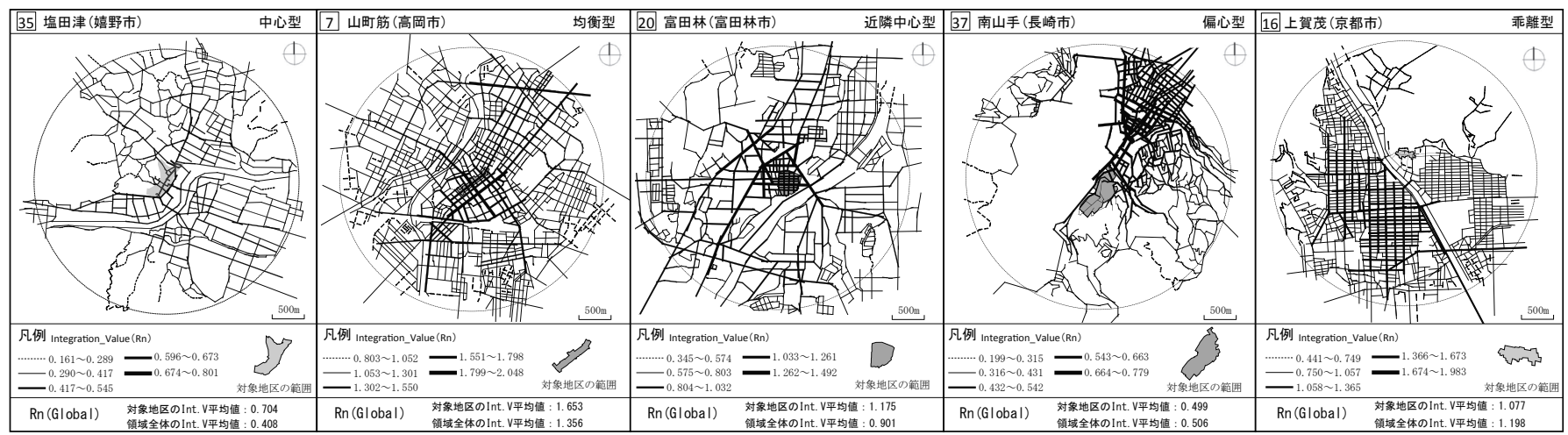

図 4 重伝建地区とその周辺地区との接続関係の例示

重伝建地区における街路空間が、地区内に占める割合を見ると、 美濃町 (92.3\%), 脇町南町 (93.3\%) は他の地区に比べて非常に高 い值となっている。つまり、これらの地区は周辺エリアに対して空 間の接続性が相対的優位であるといえる。また、段階 1 と段階 2 の 構成比の合計が $60 \%$ 以上の重伝建地区は 24 箇所で、対象地区総数の $60 \%$ に当たる。つまり、重伝建地区の大部分は、接続性の比較的な 優位の位置に立地していると伺える。

次に、範囲全体に占める割合（「範囲全体」）についてみると、各 段階において多くの対象地区の割合は $10 \%$ 以下で低い值となってい る。この結果は解析範囲内に占める重伝建地区の面積及び都市道路 の構成形態との関係があると考えられる。一方、段階 1 において、 筑後吉井 $(53.6 \%)$, 山町筋 $(42.9 \%)$, 仲町 $(33.8 \%)$ などの地区
は高い值を示したことから、これらの重伝建地区では、比較的に接 続性の良い空間がエリアの中心に集中しているといえる。

\section{3 接続関係による類型化}

以上の結果を踏まえて、40 重伝建地区とその周辺地区との接続関 係を明らかにするために、前節で算出した各段階の構成比を用い、 ウォード法によるクラスター分析を行った。その結果は表 1 に示す ように、40 重伝建地区を 5 つのグループに分けることが出来た。ま た、図 4 に示すように、各グループにおける代表的地区を取り上げ、 周辺地区との接続的関係の特徵を例示してみる。

中心型 (4 地区) : このグループの段階 1 において、「地区内部」の構 成比が $80 \%$ 以上で、他グループに比べて突出して高いことから、こ のグループの地区は、都市全体における接続性の優れた場所に位置 
している。また、同段階の「範囲全体」 の值は $15 \%$ で低く、これらの重伝建地区 は、接続性からみた中心的都市空間を占 める割合が比較的少ないことがわかった。 均衡型 (5 地区)：「地区内部」の構成比 を見ると、段階 1 から段階 3 にかけて、 值の分布にばらつきが見られた。一方、 重伝建地区の街路空間が都市全体に占め る割合は $30 \%$ で高い值となった。つまり、 このグループに関して、接続性からみた 中心的都市空間が集中しているのが特徵 である。

近隣中心型 (12 地区) : このグループの 段階 2 の構成比を見ると、「地区内部」の 值は $50 \%$ 以上で、他の段階に比べて最も 大きい。また、段階 3 及びその以降の段 階に構成している空間単位は少ないこと から、このグループの地区は、接続性か らみた中心的都市空間に近隣していると 読み取ることができる。

偏心型（14 地区）：重伝建地区における

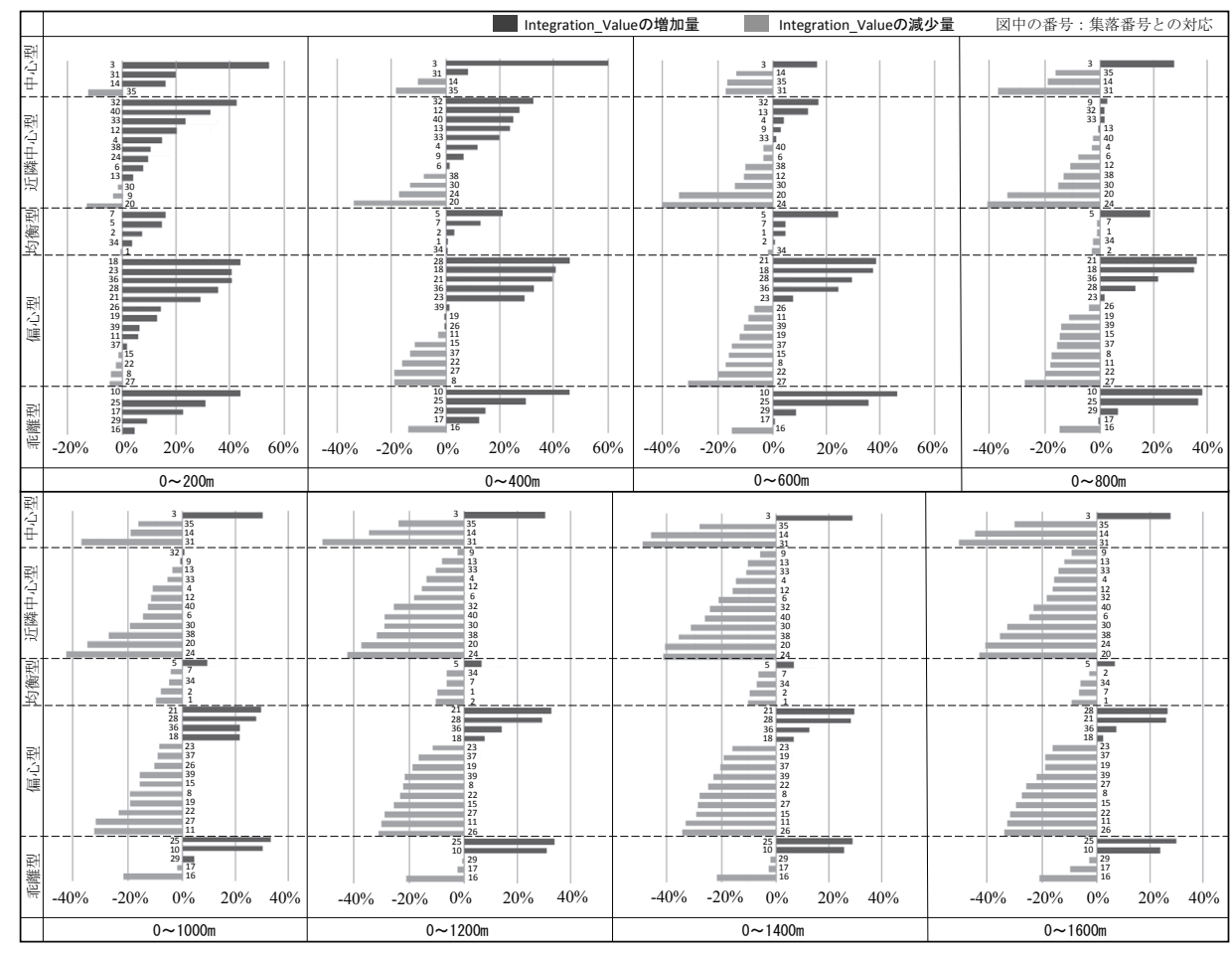

図 5 各重伝建地区における Int. V の平均値の変化傾向

街路空間の接続性は、主に段階 2 と段階 3 にあり、つまり、都市全 体の接続性において中レベルである。これより、このグループの地 区は、接続性が比較的に優位な位置からは一定の距離があると考え られる。

乘離型（5 地区）：このグループにおいて、段階 3 と段階 4 の構成比 が大きく、特に、段階 4 の構成比は他のグループに比べて最も大き いことから、これらの重伝建地区は、解析範囲全体における接続性 の劣位に位置していると言える。

以上の結果により、道路空間の接続性の観点から、重伝建地区と その周辺地区との空間的関係を明らかにした。また, 道路網の接続 性の結果から解析範囲全体における各空間単位の移動効率の相対的 な優劣を把握することで、各重伝建地区は当該都市における空間的 ポテンシャルを捉えることが可能であるといえる。

\section{4 重伝建地区の性格種別からみた接続性の特徵}

ここで、各重伝建地区の性格種別と以上の結果を比較しながら、 各地区の分類特徴を定性的に考察してみる。まず、各重伝建地区内 の Int.V の平均值をみると、在郷町 - 寺内町の 20. 富田林、22. 今井 町や商家町の 38. 豆田町、15. 八幡など地区内の接続性は高い值と なっている。これらの重伝建地区の形成起源を比較すると、共通点 として、重伝建地区が比較的平坦な地形に立地し、整然と碁盤目状 に区画がなされた町割の空間構造を持っていることが見られた。一 方、形成拠点（港、社寺の位置）の制約関係で、港町の 36. 東山手、 37. 南山手や寺町の 10. 卯辰山麓などのような重伝建地区は、山間 部また山地の隣接部に立地し、大きくカーブした道路や入り組んだ 形の道路で構成されているため、地区空間の接続性は低い值となっ た。この結果により、重伝建地区の立地環境及び街路構造の視点か ら見ると、各地区の接続性と当該地区の性格種別の間に一定の対応 関係があると考えられる。

続いて、重伝建地区と周辺地区との接続的関係から見ると、中心型、
均衡型、近隣中心型において、表通りまたは横丁に面して形成され た歴史的商業地の商家町、中世から近世の時代に商品生産の発展 · 流通に伴って発生した在郷町の占める割合が大きい。これに対して、 偏心型、乘離型において、神社や寺院を中心に形成された門前町、 社家町、寺町、主に城下や陣屋の周囲に形成された武家町及び寺社、 自然の風景地と隣接して形成された茶屋町が数多く見られた。これ より、都市部内に成立し、より強い商業機能をもつ重伝建地区ほど、 現在の中心的都市空間に近い場所に位置している傾向が示された。

\section{4. 空間接続性の変化特徵}

\section{1 周辺エリアごとの接続性の変化傾向}

周辺地区が重伝建地区の空間接続性に与えている影響を明らかに するために、重伝建地区と隣接している周辺エリアの範囲を広げな がら、重伝建地区における Int. V 平均值を算出し、その変化傾向に ついて見てみる。具体的には、周辺エリアを各重伝建地区の境界線 から 200m、400m、600m、800m、1,000m、1,200m、1,400m、1,600m の 範囲に設定した。そして、各範囲における重伝建地区の Int. V 平均 值を求めた結果（表 2 の左欄に示す）と重伝建地区内の結果をもと に, 以下の式によって、各重伝建地区の Int. V 平均値の変化率（表 2 の右欄）を算出した。

前述の接続関係で整理し、変化率の高い順に並べると、図 5 のよ うに、各重伝建地区の Int. V 平均值の変化傾向を読み取れる。まず、 周辺エリアの $200 \mathrm{~m}$ と $400 \mathrm{~m}$ の場合、Int. V 平均值の変化は $600 \mathrm{~m}$ 以降 に比べて大きく、そして大部分の地区の值は正になっていることか ら、重伝建地区に隣接している比較的狭い範囲は地区内の空間接続 性に対してプラスの影響を与えていることがわかる。そして周辺エ リアの $200 \mathrm{~m}$ から 1, 600 に にかての各範囲において、同一地区にお いても、Int. V 平均值の変化傾向は異なっており、周辺地区からの影 響は一定ではないこともわかった。一方、Int. V 平均值の変化がマイ 
表 2 各範囲区間における各地区の Int. V 平均値及びその変化率

\begin{tabular}{|c|c|c|c|c|c|c|c|c|c|c|c|c|c|c|c|c|c|c|c|}
\hline \multirow{2}{*}{ 番号 } & \multirow{2}{*}{ 名称 } & \multicolumn{9}{|c|}{ 重伝建地区のInt. V 平均值 } & \multicolumn{8}{|c|}{ 重伝建地区のInt. V平均值の変化率 } & \multirow{2}{*}{ 接繶阑俈 } \\
\hline & & om & $200 \mathrm{~m}$ & $400 \mathrm{~m}$ & $600 \mathrm{~m}$ & $800 \mathrm{~m}$ & $1000 \mathrm{~m}$ & $1200 \mathrm{~m}$ & $1400 \mathrm{~m}$ & $1600 \mathrm{~m}$ & $0 \sim 200 \mathrm{~m}$ & $0 \sim 400 \mathrm{~m}$ & $0 \sim 600 \mathrm{~m}$ & $0 \sim 800 \mathrm{~m}$ & $0 \sim 1000 \mathrm{~m}$ & $0 \sim 1200 \mathrm{~m}$ & $0 \sim 140000 \mathrm{~m}$ & $0 \sim 1600 \mathrm{~m}$ & \\
\hline 14 & 美湛町 & 1.373 & 1.591 & 1.226 & 1. 197 & 1.104 & 0.994 & 0.886 & 0.734 & 0.727 & 15.98 & $-10.7 \%$ & $-12.8 \%$ & $-19.6 \%$ & $-27.6 \%$ & $-35.5 \%$ & $-46.6 \%$ & -47.10 & 中心型 \\
\hline 35 & 塩田津 & 1.056 & 0.919 & 0.858 & 0.885 & 0.880 & 0.833 & 0.794 & 0.754 & 0.721 & $-12.9 \%$ & $-18.7 \%$ & $-16.1 \%$ & $-16.7 \%$ & $-21.2 \%$ & $-24.8 \%$ & $-28.6 \%$ & $-31.7 \%$ & 中心型 \\
\hline 3 & 中町 & 1. 235 & 1.906 & 1.979 & 1.438 & 1. 584 & 1. 598 & 1. 602 & 1. 585 & 1. 581 & $54.3 \%$ & $60.2 \%$ & $16.4 \%$ & $28.3 \%$ & $29.4 \%$ & $29.7 \%$ & $28.3 \%$ & 28.08 & 中心型 \\
\hline 31 & 脇町南町 & 1.405 & 1.684 & 1.516 & 1.166 & 0.869 & 0.662 & 0.663 & 0.674 & 0.654 & 19.98 & $7.9 \%$ & $-17.0 \%$ & $-38.2 \%$ & $-52.9 \%$ & $-52.8 \%$ & $-52.0 \%$ & $-53.5 \%$ & 中心型 \\
\hline 32 & 宇和町卯之町 & 0.831 & 1.183 & 1.096 & 0.970 & 0.846 & 0.834 & 0.614 & 0.651 & 0.670 & 42.38 & $31.9 \%$ & $16.7 \%$ & $1.8 \%$ & $0.4 \%$ & $-26.1 \%$ & $-21.7 \%$ & $-19.3 \mathrm{~m}$ & 近隣中心型 \\
\hline 6 & 佐原 & 1. 157 & 1. 248 & 1. 167 & 1. 120 & 1. 065 & 0.989 & 0.942 & 0.870 & 0.851 & $7.8 \%$ & $0.9 \%$ & $-3.2 \%$ & $-8.0 \%$ & $-14.6 \%$ & $-18.6 \%$ & $-24.8 \%$ & -26.50 & 近隣中心型 \\
\hline 20 & 富田林 & 2. 273 & 1. 963 & 1. 489 & 1. 500 & 1. 481 & 1. 469 & 1. 397 & 1. 323 & 1. 243 & $-13.6 \%$ & $-34.5 \%$ & $-34.0 \%$ & $-34.8 \%$ & $-35.3 \%$ & $-38.5 \%$ & $-41.8 \%$ & $-45.3 \%$ & 近隣中心型 \\
\hline 30 & 柳井 & 1. 508 & 1. 479 & 1. 306 & 1. 301 & 1. 275 & 1. 218 & 1. 060 & 1. 030 & 0.990 & $-2.0 \%$ & $-13,4 \%$ & $-13.7 \%$ & $-15.5 \%$ & $-19.3 \%$ & $-29.7 \%$ & $-31.7 \%$ & $-34.4 \%$ & 近隣中心型 \\
\hline 38 & 豆田町 & 1.731 & 1. 913 & 1. 591 & 1. 566 & 1. 501 & 1. 254 & 1. 163 & 1. 104 & 1. 087 & $10.5 \%$ & $-8.1 \%$ & $-9.5 \%$ & $-13.3 \%$ & $-27.5 \%$ & $-32.8 \%$ & $\begin{array}{l}-36.2 \% \\
-3 \%\end{array}$ & $-37.2 \%$ & 近隣中心型 \\
\hline 9 & 主計町 & 1. 247 & 1. 199 & 1. 325 & 1. 285 & 1. 279 & 1. 246 & 1. 217 & 1. 170 & & $-3.9 \%$ & 6.28 & $3.1 \%$ & $2.6 \mathrm{w}$ & $-0.1 \%$ & $-2.4 \%$ & $-6.2 \%$ & $-9.9 \%$ & 近隣中心型 \\
\hline 12 & 三町 & 1.578 & 1.896 & 2. 000 & & & 397 & & 1.3 & & 20.28 & 26.78 & $-10.1 \%$ & $-10.9 \%$ & $-11.5 \%$ & $-15.8 \%$ & $-16.7 \%$ & $-16.9 \%$ & 近隣中心型 \\
\hline 24 & 打吹玉川 & 1. 494 & 1.638 & 1. 233 & & 0.866 & 0.856 & 0.842 & 0.859 & 0.851 & 9. $6 \%$ & $-17.5 \%$ & -40.38 & $-42.1 \%$ & $-42.7 \%$ & $-43.6 \%$ & $-42.5 \%$ & $-43.1 \%$ & 近隣中心型 \\
\hline 4 & 真壁 & 1. 298 & 1. 485 & 1. 442 & 1. 349 & 1. 258 & 1. 155 & 1. 112 & 1. 105 & 1.086 & 14. $4 \%$ & 11. $1 \%$ & $3.9 \%$ & $-3.1 \%$ & $-11.0 \%$ & $-14.4 \%$ & $-14.9 \%$ & $-16.4 \%$ & 近隣中心型 \\
\hline 13 & 下二之町大新町 & 1.412 & 1.467 & 1.742 & 1. 595 & 1.410 & 1. 355 & 1. 297 & 1. 262 & 1. 235 & $3.9 \%$ & $23.4 \%$ & $12.9 \%$ & $-0.2 \%$ & $-4.0 \%$ & $-8.2 \%$ & $-10.6 \%$ & $-12.5 \%$ & 近隣中心型 \\
\hline 34 & 筑後吉井 & 1.222 & 1.268 & 1.223 & 1.205 & 1.193 & 1.159 & 1. 140 & 1.136 & 1.141 & $3.7 \%$ & 0.18 & $-1.4 \%$ & $-2.4 \%$ & $-5.2 \%$ & -6.78 & $-7.0 \%$ & $-6.6 \%$ & 均衡型 \\
\hline 1 & 元町 - 未広町 & 1. 566 & 1.548 & 1. 571 & 1. 637 & 1. 551 & 1. 408 & 1.412 & 1.401 & 1.416 & $-1.2 \%$ & $0.4 \%$ & 4. $5 \%$ & $-0.9 \%$ & $-10.1 \%$ & $-9.8 \%$ & $-10.5 \%$ & $-9.6 \%$ & 均衡型 \\
\hline 2 & 仲町 & 1.378 & 1. 480 & 1.414 & 1. 391 & 1. 340 & 1. 271 & 1. 229 & 1. 240 & & 7. $4 \%$ & $2.6 \%$ & $0.9 \%$ & $-2.8 \%$ & $-7.8 \%$ & $-10.8 \%$ & $-10.0 \%$ & -3. & 均衡型 \\
\hline 5 & 川越 & 1.450 & & & & & & & & & & $20.5 \%$ & & $18.7 \%$ & $8.9 \%$ & $6.0 \%$ & $6.5 \%$ & 6. & 均衡型 \\
\hline $\begin{array}{l}5 \\
7 \\
\end{array}$ & 山町筋 & $\begin{array}{l}1.450 \\
1.792 \\
\end{array}$ & $\begin{array}{l}1.064 \\
2.081\end{array}$ & & & $\begin{array}{l}1.212 \\
1.779 \\
\end{array}$ & $\begin{array}{l}1.58 \\
1.715 \\
\end{array}$ & $\begin{array}{l}1.5 \\
1.6 \\
\end{array}$ & $\begin{array}{l}1.544 \\
1.671 \\
\end{array}$ & & $\begin{array}{l}14.8 \% \\
16.1 \% \\
\end{array}$ & $\begin{array}{l}20.5 \% \\
12.3 \% \\
\end{array}$ & $\begin{array}{l}24.2 \% \\
5.0 \% \\
\end{array}$ & $\begin{array}{l}18.16 \\
-0.7 \% \\
\end{array}$ & $\begin{array}{r}8.9 \% \\
-4.3 \% \\
\end{array}$ & $\begin{array}{r}6.0 \% \\
-6.8 \% \\
\end{array}$ & $\begin{array}{r}6.5 \% \\
-6.8 \% \\
\end{array}$ & $\begin{array}{c}6 . \\
-7 . \\
\end{array}$ & 均德型 \\
\hline 18 & 祇園新橋 & 1.237 & 1.778 & 1.735 & 1.689 & 1.677 & 1. 1.492 & 1. 329 & 1.313 & 1. 261 & $43.7 \%$ & 40. 3\% & $36.5 \%$ & $35.5 \%$ & $20.6 \%$ & $7.4 \%$ & 6. $1 \%$ & 1. & 偏心型 \\
\hline 21 & 簙山 & 0.770 & 0. & $\begin{array}{l}1.07 \\
\end{array}$ & & & & & & & 28. & $39.2 \%$ & 38. & $36.5 \%$ & 28. & $31.9 \%$ & 29. $1 \%$ & 26. & 偏心型 \\
\hline 36 & 東山手 & 0.571 & & & $\begin{array}{l}0.708 \\
0.78\end{array}$ & $\begin{array}{l}0.698 \\
0.698\end{array}$ & 0.689 & 0.650 & & & $40.5 \%$ & $32.3 \%$ & $24.1 \%$ & $\begin{array}{l}32.0 \% \\
22.2 \%\end{array}$ & $20.8 \%$ & $\begin{array}{l}13.8 \% \\
13.8 \%\end{array}$ & $12.3 \%$ & $\begin{array}{r}\text { 7. } 2 \% \\
\end{array}$ & 偏心型 \\
\hline 8 & 東山ひがし & 1. 391 & & & & & & & & & $-4.1 \%$ & $-19.3 \%$ & $-16.8 \%$ & $-17.9 \%$ & $-19.3 \%$ & $-22.7 \%$ & $-28.5 \%$ & $-29.0 \%$ & 偏心型 \\
\hline 15 & 八幡 & 1. 647 & & & & 1. 4 & & 1. 2 & & & -1 & $-11.5 \%$ & $-15.6 \%$ & $-14.7 \%$ & $-16.0 \%$ & -26.28 & $-29.8 \%$ & -31. & 偏心型 \\
\hline 37 & 南山手 & 0.617 & 0.628 & 0.536 & 0.526 & 0.520 & 0.558 & 0.512 & 0.490 & 0.4 & $\begin{array}{l}1.8 \% \\
1.8 \%\end{array}$ & $-13.2 \%$ & $-14.7 \%$ & $\begin{array}{l}-15.0 \% \\
-15 \%\end{array}$ & $-9.5 \%$ & $-17.0 \%$ & $-20.6 \%$ & $-20.1 \%$ & 偏心型 \\
\hline 19 & 崕峨鳥居本 & 0.806 & 0.911 & $\begin{array}{l}0.803 \\
0.803\end{array}$ & $\begin{array}{l}0.709 \\
0.09\end{array}$ & 0.714 & $\begin{array}{l}0.649 \\
0.649\end{array}$ & $\begin{array}{l}0.652 \\
0.652\end{array}$ & 0.650 & $\begin{array}{l}. .43 \\
0.643\end{array}$ & $\begin{array}{l}1.00 \\
13.0 \%\end{array}$ & $-0.4 \%$ & $-12.0 \%$ & $\begin{array}{l}-11.5 \% \\
-11.5 \%\end{array}$ & $\begin{array}{r}-19.5 \% \\
-19.5 \%\end{array}$ & $-19.2 \%$ & $-19.4 \%$ & $\begin{array}{l}-20.12 \\
-20\end{array}$ & 偏心型 \\
\hline 23 & 五條新町 & 0.979 & 1. 378 & 1. 263 & & 0.995 & 0.895 & 0.88 & 0.8 & & $40.7 \%$ & $28.9 \%$ & $7.4 \%$ & $1.6 \%$ & $-8.7 \%$ & $-11.6 \%$ & $-16.4 \%$ & -17. & 偏心型 \\
\hline 27 & 堀 & $\begin{array}{l}\text { 1. } 516 \\
\text { S }\end{array}$ & & & & & & & & & $-4.6 \%$ & $-19.3 \%$ & $-30.9 \%$ & $-28.2 \%$ & -31 . & & & & 偏心 \\
\hline 11 & & & & & & & & & & & & -3 & & & & & & & \\
\hline $\begin{array}{l}11 \\
28\end{array}$ & & & & & & & & & & & 35. & 45. & 29. & 13 & & & & & \\
\hline 39 & & & & & & & & & & & 6. & 1. & -10 & & $-15.8 \%$ & -22.0 & -23 & & \\
\hline 10 & & & & & & & & & & & 43. & $45.3 \%$ & 45. & $38.7 \%$ & 29. & $30.1 \%$ & $24.7 \%$ & 23 & 排竞 \\
\hline 25 & 仓 & & 0.9 & 0.9 & 1.0 & 1.0 & & & & & 30.7 & 29. & 35. & $37.4 \%$ & $32.2 \%$ & $33.3 \%$ & 28. $2 \%$ & 30. & 邦離型 \\
\hline 16 & 上賀茂 & 1. 418 & 1. 482 & 1. 220 & $\begin{array}{l}\text { 1. } 209 \\
\text { S }\end{array}$ & $\begin{array}{l}\text { 1. } 206 \\
\text { S }\end{array}$ & 1. 104 & $\begin{array}{l}1.115 \\
\text { 1. }\end{array}$ & 1.1 & 1.1 & 4. $5 \%$ & $-14.0 \%$ & $-14.77^{\circ}$ & $-14.9 \%$ & $-22.1 \%$ & $-21.4 \%$ & $-21.9 \%$ & $-22.3 \%$ & 北離型 \\
\hline 17 & 産蜜坂 & 0.896 & 1.096 & 1. 001 & 0.899 & 0.896 & 0.878 & 0.874 & 0.871 & 0.867 & 22. 3\% & $11.7 \%$ & $0.3 \%$ & $0.0 \%$ & $-2.0 \%$ & $-2.5 \%$ & $-2.8 \%$ & -3.38 & 非離型 \\
\hline 29 & 浜崎 & 1. 333 & 1.453 & 1. 521 & 1. 449 & 1. 421 & 1. 388 & 1. 323 & 1. 302 & 1. 196 & $9.0 \%$ & $14.1 \%$ & $8.7 \%$ & $6.6 \%$ & 4. $1 \%$ & $-0.7 \%$ & $-2.4 \%$ & $-10.2 \%$ & 排離型 \\
\hline
\end{tabular}

ナスになっているところについて見ると、周辺エリアの範囲の拡大 に伴って、マイナスの影響を受けている地区の数が増加傾向にある。 また、1. 元町・末広町、2. 仲町、7. 山町筋、9. 主計町、29. 浜崎と 34. 筑後吉井の 6 地区（表 2 の点線で示す）では、 $200 \mathrm{~m}$ から $1,600 \mathrm{~m}$ にかけての各範囲において、Int. V 平均值の変化率がほぼ $10 \%$ 以下 で低い值（表 2 の右欄に示す）となっていることから、それらの周 辺エリアは、重伝建地区の接続性にあまり影響していないことがわ かった。

以上のことを踏まえて、表 2 の右欄に参照し、図 5 及び前述の「重 伝建地区と周辺地区の接続関係」から、周辺エリアごとの接続性の 変化傾向についてみると、周辺エリアの範囲が大きくなるにつれて、 接続性の受けている影響は変化しており、「近隣中心型」では 0 〜 1,000m 以上になると、すべての地区はマイナス影響を受けているこ とに対して、「偏心型」と「乘離型」のグループでは、常にプラス影 響を受けている地区は存在していることから、中心的都市空間と乘 離している重伝建地区ほど、プラスの影響を与える範囲は比較的広 くなり、地区内部の交通効率が向上される傾向がある。一方、「均衡 型」の重伝建地区では、周辺エリアの範囲拡大に伴って、同一地区 の Int. V 平均值の変化は少なく、また変化率はほぼ $10 \%$ と低いこと から、この類型の重伝建地区において、周辺道路は地区内の接続性 に与えている影響が弱いと考えられる。

\section{2 周辺エリア影響の寄与範囲}

次に、前節で算出した各範囲区間の Int. V 平均值を用いて、周辺 エリアが重伝建地区の空間接続性に与えている影響において、どの ような範囲の周辺エリアが最も寄与しているのかを明らかにする。 ここでは修正寄与率を用いることにした。寄与率とは、ある指標や 数值が、全体の変化に対してどの程度貢献したのかを示寸数值であ る。本研究の修正寄与率注 5 の算出方法について、以下に示す。

\begin{abstract}
修正寄与率 $(\%)=\mid\left(\right.$ Int. $V_{\mathrm{n}+1}-$ Int. $\left.\mathrm{V}_{\mathrm{n}}\right) / \sum_{i=0}^{n}$ Int. $\mathrm{V}_{i} \mid$
Int. Vn : 周辺エリアの $200 \mathrm{~m} \sim 1600 \mathrm{~m}$ における重伝建地区の Int. V平均值 $(\mathrm{n}: 200 \sim 1600 \mathrm{~m})$ $\Delta \mathrm{Int} . \mathrm{V}_{\mathrm{i}}: 200 \mathrm{~m}$ から $1600 \mathrm{~m}$ にかけて、各範囲区間におけるInt. V平均値の変化量
\end{abstract}

算出結果（表 3 の左欄に示す）をみると、まず多くの重伝建地区 において、0〜 200m と 200m〜400m の両範囲区間での寄与率は最大 值を取っている。つまり、周辺エリアが重伝建地区の空間接続性に 与えている影響に関して、400m 以内の周辺エリアは最も寄与してい ることが分かった。そして、1,200m から $1,600 \mathrm{~m}$ にかけては、多くの 值は $5 \%$ 以下となっており、他の範囲区間に比べて突出して低い。こ の結果より、重伝建地区の周辺エリアにおいて、1,200m 範囲以降の 街路空間は、重伝建地区の接続性にあまり寄与していないことが明 らかとなった。

また、具体的に各地区の接続性の寄与範囲及びそれによる地区間 の共通な特徵を把握するために、各範囲区間の寄与率を用い、ウォー ド法によるクラスター分析を行った。その結果、40 重伝建地区を 4 つのグループに分けられた。さらに、各グループにおける寄与範囲 の変化特徴を明確に示すために、図 6 のように類型ごとに各範囲区 間の平均寄与率及び平均累積寄与率を算出した。

「類型 I」に関して、0m〜200m の範囲区間の寄与率は $50 \%$ を超 え、ほかの区間に比べて突出している。また、200m 以降の各範囲区 間における寄与率が 10\%以下で、非常に低い值となった。このこと より、このグループにおいて、重伝建地区と隣接している $200 \mathrm{~m}$ の周 辺エリアは、地区の空間接続性に最も寄与していることがわかった。 「類型 II」の重伝建地区では、200m 〜 400m 範囲区間の寄与率が最も 大きく、 $0 \mathrm{~m} \sim 400 \mathrm{~m}$ の周辺エリアは、当該地区の空間接続性に与えて いる影響において $50 \%$ 以上寄与している。但し、15.八幡、26. 竹原 地区、30. 柳井などの地区では、 $1,000 \mathrm{~m} \sim 1,200 \mathrm{~m}$ の範囲区間の寄与 率は $30 \%$ 以上となったため、1,200m の周辺エリアが重伝建地区の接 続性に与える影響も顕著であることがわかる。「類型III」の寄与率を 
表 3 対象地区における各範囲区間の寄与率と道路ネットワークの形態に関する指標值

\begin{tabular}{|c|c|c|c|c|c|c|c|c|c|c|c|c|c|c|c|c|c|}
\hline \multirow[b]{2}{*}{ 類型 } & \multirow[b]{2}{*}{ 番号 } & \multirow[b]{2}{*}{ 名称 } & \multicolumn{8}{|c|}{ 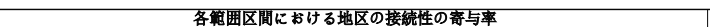 } & \multicolumn{6}{|c|}{ 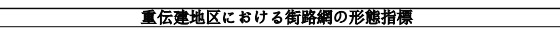 } & \multirow[b]{2}{*}{ 接続閶你 } \\
\hline & & & $\begin{array}{c}0 \sim \\
200 \mathrm{~m}\end{array}$ & $\begin{array}{l}200 \mathrm{~m} \sim \\
400 \mathrm{~m}\end{array}$ & $\begin{array}{l}400 \mathrm{~m} \\
600 \mathrm{~m}\end{array}$ & $\begin{array}{l}600 \mathrm{~m} \sim \\
800 \mathrm{~m}\end{array}$ & $\begin{array}{l}800 \mathrm{~m} \sim \\
1000 \mathrm{~m}\end{array}$ & $\begin{array}{l}1000 \mathrm{~m} \sim \\
1200 \mathrm{~m}\end{array}$ & $\begin{array}{c}1200 \mathrm{~m} \sim \\
1400 \mathrm{~m}\end{array}$ & $\begin{array}{c}1400 \mathrm{~m} \sim \\
1600 \mathrm{~m}\end{array}$ & Links & Island & GA & $\mathbf{A R}$ & AA & 性格種别 & \\
\hline \multirow{7}{*}{ 類型 I } & 32 & 宇和町卯之町 & $36 \%$ & $9 \%$ & $13 \%$ & $13 \%$ & $1 \% 1 \%$ & $23 \%$ & $4 \%$ & $2 \%$ & 18 & 4 & 0.33 & 0.13 & 0.22 & $\begin{array}{l}\text { 在郷町 } \\
\end{array}$ & 近隣中心型 \\
\hline & 18 & 䙉園新橋 & $51 \%$ & $4 \%$ & $4 \%$ & $1 \%$ & $17 \%$ & $15 \%$ & $1 \%$ & $5 \%$ & 9 & 4 & 0.27 & 0.31 & 0.44 & 茶屋町 & 偏心型 \\
\hline & 21 & 簿山 & $50 \%$ & $17 \%$ & $2 \%$ & $3 \%$ & $12 \%$ & $6 \%$ & $5 \%$ & $5 \%$ & 58 & 15 & 0.17 & 0.14 & 0.26 & 城下町 & 偏心型 \\
\hline & 36 & 束山手 & $55 \%$ & $11 \%$ & $11 \%$ & $3 \%$ & $2 \%$ & $9 \%$ & $2 \%$ & $7 \%$ & 41 & 6 & 0.17 & 0.08 & 0.15 & 港町 & 偏心型 \\
\hline & 10 & 卯辰山蔍 & $63 \%$ & $2 \%$ & $1 \%$ & $10 \%$ & $14 \%$ & $1 \%$ & $8 \%$ & $1 \%$ & 110 & 44 & 0.14 & 0.20 & 0.40 & 寺町 & 乘離型 \\
\hline & 25 & 仓敳 & $57 \%$ & $3 \%$ & $11 \%$ & $4 \%$ & $10 \%$ & $2 \%$ & $9 \%$ & $5 \%$ & 70 & 19 & 0.15 & 0.14 & 0.27 & 商家町 & 邦離型 \\
\hline & \multicolumn{2}{|r|}{ 平均值 } & $52 \%$ & $8 \%$ & $7 \%$ & $5 \%$ & $9 \%$ & $9 \%$ & $5 \%$ & $4 \%$ & 51 & 15 & 0.20 & 0.17 & 0.29 & & \\
\hline \multirow{14}{*}{ 類型 II } & 14 & 美濃町 & $20 \%$ & $34 \%$ & $3 \%$ & $14 \%$ & $10 \%$ & $10 \%$ & $9 \%$ & $1 \%$ & 13 & 6 & 0.53 & 0.29 & 0.46 & 商家町 & 中心型 \\
\hline & 35 & 㙁田津 & $35 \%$ & $16 \%$ & $7 \%$ & $1 \%$ & $12 \%$ & $10 \%$ & $11 \%$ & $8 \%$ & 32 & 4 & 0.19 & 0.07 & 0.13 & 商家町 & 中心型 \\
\hline & 34 & 筑後吉井 & $25 \%$ & $24 \%$ & $10 \%$ & $7 \%$ & $18 \%$ & $10 \%$ & $2 \%$ & $3 \%$ & 62 & 29 & 0.21 & 0.24 & 0.47 & 在郷町 & 均衡型 \\
\hline & 6 & 佐原 & $19 \%$ & $17 \%$ & $10 \%$ & $15 \%$ & $16 \%$ & $10 \%$ & $11 \%$ & $4 \%$ & 21 & 11 & 0.41 & 0.30 & 0.52 & 商家町 & 近隣中心型 \\
\hline & 20 & 富田林 & $29 \%$ & $45 \%$ & $1 \%$ & $2 \%$ & $1 \%$ & $7 \%$ & $7 \%$ & $8 \%$ & 20 & 30 & 0.65 & 0.86 & 1.50 & 在郷町 - 寺内町 & 近隣中心型 \\
\hline & 30 & 构井 & $6 \%$ & $33 \%$ & $1 \%$ & $5 \%$ & $11 \%$ & $30 \%$ & $6 \%$ & $8 \%$ & 11 & 1 & 0.36 & 0.06 & 0.09 & 商家町 & 近隣中心型 \\
\hline & 38 & 豆田町 & $18 \%$ & $32 \%$ & $2 \%$ & $6 \%$ & $24 \%$ & $9 \%$ & $6 \%$ & $2 \%$ & 18 & 8 & 0.43 & 0.26 & 0.44 & 商家町 & |近隣中心型 \\
\hline & 8 & 東山ひがし & $12 \%$ & $45 \%$ & $7 \%$ & $17 \%$ & $4 \%$ & $10 \%$ & $3 \%$ & $1 \%$ & 28 & 17 & 0.37 & 0.33 & 0.61 & 茶屋町 & 偏心型 \\
\hline & 15 & 八擤 & $5 \%$ & $30 \%$ & $13 \%$ & $3 \%$ & $4 \%$ & $31 \%$ & $11 \%$ & $5 \%$ & 16 & 11 & 0.54 & 0.41 & 0.69 & 商家町 & 偏心型 \\
\hline & 22 & 今井町 & $10 \%$ & $52 \%$ & $14 \%$ & $2 \%$ & $12 \%$ & $1 \%$ & $6 \%$ & $4 \%$ & 39 & 45 & 0.40 & 0.62 & 1.15 & 在郷町 - 寺内町 & 偏心型 \\
\hline & 26 & 竹原地区 & $20 \%$ & $21 \%$ & $9 \%$ & $3 \%$ & $9 \%$ & $31 \%$ & $5 \%$ & $1 \%$ & 24 & 4 & 0.25 & 0.09 & 0.17 & 製塩町 & 偏心型 \\
\hline & 37 & 南山手 & $5 \%$ & $40 \%$ & $4 \%$ & $3 \%$ & $17 \%$ & $20 \%$ & $10 \%$ & $1 \%$ & 97 & 15 & 0.10 & 0.08 & 0.15 & 港町 & 偏心型 \\
\hline & 16 & 上賀茂 & $14 \%$ & $56 \%$ & $2 \%$ & $1 \%$ & $22 \%$ & $2 \%$ & $2 \%$ & $1 \%$ & 10 & 0 & 0.20 & 0.00 & 0.00 & 社家町 & 飛離型 \\
\hline & \multicolumn{2}{|c|}{ 平均值 } & $17 \%$ & $34 \%$ & $6 \%$ & $6 \%$ & $12 \%$ & $14 \%$ & $7 \%$ & $4 \%$ & 30 & 14 & 0.34 & 0.28 & 0.49 & & \\
\hline \multirow{12}{*}{ 類型III } & 3 & 中町 & $46 \%$ & $5 \%$ & $37 \%$ & $10 \%$ & $1 \%$ & $0 \%$ & $1 \%$ & $0 \%$ & 6 & 0 & 0.33 & 0.00 & 0.00 & 商家町 & 中心型 \\
\hline & 31 & 腈町南町 & $21 \%$ & $13 \%$ & $26 \%$ & $22 \%$ & $15 \%$ & $0 \%$ & $1 \%$ & $2 \%$ & 15 & 6 & 0.46 & 0.24 & 0.40 & 商家町 & 中心型 \\
\hline & 9 & 主言町 & $13 \%$ & $34 \%$ & $11 \%$ & $2 \%$ & $13 \%$ & $12 \%$ & $9 \%$ & $8 \%$ & 8 & 2 & 0.60 & 0.18 & 0.25 & 茶屋町 & 近隣中心型 \\
\hline & 12 & 三町 & $29 \%$ & $9 \%$ & $52 \%$ & $1 \%$ & $1 \%$ & $6 \%$ & $1 \%$ & $0 \%$ & 9 & 4 & 0.67 & 0.31 & 0.44 & 商家町 & 近隣中心型 \\
\hline & 24 & 打吹玉川 & $15 \%$ & $42 \%$ & $35 \%$ & $3 \%$ & $1 \%$ & $1 \%$ & $2 \%$ & $1 \%$ & 31 & 17 & 0.33 & 0.30 & 0.55 & 商家町 & 近隣中心型 \\
\hline & 33 & 八女福島 & $37 \%$ & $6 \%$ & $29 \%$ & $0 \%$ & $12 \%$ & $8 \%$ & $1 \%$ & $6 \%$ & 49 & 22 & 0.23 & 0.24 & 0.45 & 商家町 & 近隣中心型 \\
\hline & 40 & 知覧 & $32 \%$ & $8 \%$ & $27 \%$ & $1 \%$ & $10 \%$ & $16 \%$ & $3 \%$ & $2 \%$ & 21 & 2 & 0.23 & 0.05 & 0.10 & 武家町 & 近隣中心型 \\
\hline & 19 & 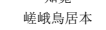 & $27 \%$ & $28 \%$ & $24 \%$ & $1 \%$ & $17 \%$ & $1 \%$ & $1 \%$ & $2 \%$ & 20 & 1 & 0.20 & 0.03 & 0.05 & 門前町 & 偏心型 \\
\hline & 23 & 五條新町 & $41 \%$ & $12 \%$ & $22 \%$ & $6 \%$ & $10 \%$ & $3 \%$ & $5 \%$ & $1 \%$ & 64 & 19 & 0.17 & 0.15 & 0.30 & 商家町 & 偏心型 \\
\hline & 27 & 堀内地区 & $11 \%$ & $35 \%$ & $28 \%$ & $6 \%$ & $9 \%$ & $6 \%$ & $1 \%$ & $5 \%$ & 35 & 19 & 0.31 & 0.29 & 0.54 & 武家町 & 偏心型 \\
\hline & 17 & 离紫坂 & $47 \%$ & $22 \%$ & $24 \%$ & $1 \%$ & $4 \%$ & $1 \%$ & $1 \%$ & $1 \%$ & 43 & 8 & 0.18 & 0.10 & 0.19 & 門前町 & 牢離型 \\
\hline & \multicolumn{2}{|r|}{ 平均值 } & 2996 & $19 \%$ & $294 \mathrm{~W}$ & $5 \%$ & $8 \%$ & $5 \%$ & $2 \%$ & $20 \mathrm{~W}$ & 27 & 9 & 0.32 & 0.17 & 0.30 & & \\
\hline \multirow{11}{*}{ 類型IV } & 1 & 元町 $\cdot$ 末広町 & $5 \%$ & $7 \%$ & $18 \%$ & $24 \%$ & $39 \%$ & $1 \%$ & $3 \%$ & $4 \%$ & 32 & 26 & 0.38 & 0.44 & 0.81 & 港町 & 均衡型 \\
\hline & 2 & 仲町 & $22 \%$ & $14 \%$ & $20 \%$ & $11 \%$ & $15 \%$ & $9 \%$ & $2 \%$ & $5 \%$ & 21 & 6 & 0.33 & 0.16 & 0.29 & 武家町 & 均衡型 \\
\hline & 5 & 川越 & $34 \%$ & $13 \%$ & $9 \%$ & $13 \%$ & $23 \%$ & $7 \%$ & $1 \%$ & $0 \%$ & 13 & 8 & 0.59 & 0.38 & 0.62 & 商家町 & 均衡型 \\
\hline & 7 & 山町筋 & $41 \%$ & $10 \%$ & $18 \%$ & $14 \%$ & $9 \%$ & $6 \%$ & $0 \%$ & $1 \%$ & 12 & 9 & 0.67 & 0.47 & 0.75 & 商家町 & 均衡型 \\
\hline & 4 & 真壁 & $32 \%$ & $7 \%$ & $16 \%$ & $15 \%$ & $18 \%$ & $7 \%$ & $1 \%$ & $3 \%$ & 25 & 16 & 0.40 & 0.36 & 0.64 & 在郷町 & 近隣中心型 \\
\hline & 13 & 下二之町大新町 & $7 \%$ & $33 \%$ & $18 \%$ & $22 \%$ & $7 \%$ & $7 \%$ & $4 \%$ & $3 \%$ & 16 & 11 & 0.54 & 0.41 & 0.69 & 商家町 & 近隣中心型 \\
\hline & 11 & 小浜西組 & $12 \%$ & $18 \%$ & $12 \%$ & $20 \%$ & $29 \%$ & $3 \%$ & $6 \%$ & $1 \%$ & 36 & 15 & 0.27 & 0.22 & 0.42 & 商家町·杂屋町 & 偏心型 \\
\hline & 28 & 平安古地区 & $37 \%$ & $11 \%$ & $17 \%$ & $17 \%$ & $14 \%$ & $2 \%$ & $1 \%$ & $1 \%$ & 8 & 1 & 0.50 & 0.09 & 0.13 & 武家町 & 偏心型 \\
\hline & 39 & 出水蔍 & $17 \%$ & $15 \%$ & $31 \%$ & $11 \%$ & $4 \%$ & $17 \%$ & $4 \%$ & $1 \%$ & 109 & 30 & 0.12 & 0.14 & 0.28 & 武家町 & 偏心型 \\
\hline & 29 & 港踦 & $23 \%$ & $13 \%$ & $14 \%$ & $21 \%$ & $6 \%$ & $13 \%$ & $4 \%$ & $5 \%$ & 38 & 19 & 0.28 & 0.27 & 0.50 & 港町 & 非離型 \\
\hline & & 巨均值 & $23 \%$ & $14 \%$ & $17 \%$ & $17 \%$ & $16 \%$ & $7 \%$ & $3 \%$ & $2 \%$ & 31 & 14 & 0.41 & 0.29 & 0.51 & & \\
\hline
\end{tabular}
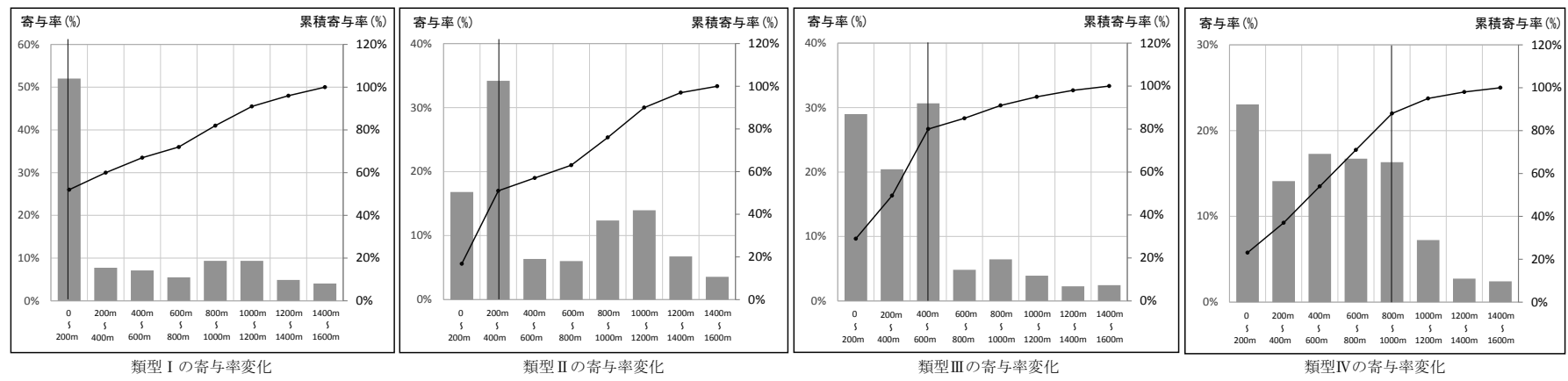

図 6 各類型の寄与率変化と累積寄与率

需与率 (平均) 一累積寄与率(平均)

\begin{tabular}{|c|c|c|c|c|c|}
\hline & 類型 I & 類型 II & 類型III & 類型IV & 合計 \\
\hline 中心型 & & 2 & 2 & & 4 \\
\hline 近隣中心型 & 1 & 4 & 5 & 2 & 12 \\
\hline 均衡型 & & 1 & & 4 & 5 \\
\hline 偏心型 & 3 & 5 & 3 & 3 & 14 \\
\hline 乘離型 & 2 & 1 & 1 & 1 & 5 \\
\hline 合計 & 6 & 13 & 11 & 10 & 40 \\
\hline
\end{tabular}

図 7 接続関係と周辺エリア影響の寄与範囲のクロス集計

みると、0m〜200m、200m 〜 400m と $400 \mathrm{~m} \sim 600 \mathrm{~m}$ の 3 範囲区間で高 い值になっており、0 $\sim 600 \mathrm{~m}$ の累積寄与率は $80 \%$ を超える結果と なったことから、このグループの重伝建地区において、600m 範囲の 周辺エリアは地区内の接続性に主に影響している。「類型IV」に関し て、周辺エリアの $200 \mathrm{~m}$ から $1,000 \mathrm{~m}$ にかけて、寄与率の值が比較的 平均的に分布していることが見られた。つまり、このグループでは、 周辺エリアが重伝建地区の接続性に与える影響は比較的安定である。 よって、図 7 に示寸ように、このグループにおいて、周辺エリアが
それらの地区の接続性に与える影響の寄与範囲は $1,000 \mathrm{~m}$ という広い 範囲になったことが明らかとなった。

\section{3 接続関係と周辺エリア影響の寄与範囲の関係性}

ここで、前節の「重伝建地区と周辺地区の接続関係」と「周辺エ リア影響の寄与範囲」を照らし合わせ、図 7 のクロス集計に示すよ うに、各類型における重伝建地区の分布状況及びその特徴について 見てみる。まず、「中心型」と「近隣中心型」では、類型 II と類型 III に属している地区の数が最も多いことから、中心的都市空間と近隣 している重伝建地区では、地区の接続性に影響する範囲は主に最小 $400 \mathrm{~m}$ から最大 $600 \mathrm{~m}$ までの周辺エリアに寄与している。次に、「偏心 型」と「乘離型」について、重伝建地区の分布にばらつきが見られた。 このことから、都市空間と乘離している重伝建地区で、接続性の受 けている影響は安定せず、常に変化している。一方、「均衡型」の グループでは、類型IVの地区の数が最も多いことから、都市空間に 大きく構成している重伝建地区ほど、地区の接続性に影響する範囲 は比較的広いことがわかった。 


\section{4 街路ネットワークの形態からみた各類型の特徴}

以上のことを踏まえながら、ここで重伝建地区においてAxial Line で構成している街路ネットワークの形態から、前節で類型化 した各地区の特徴について考察を行った。具体的に SS 理論に基づ き、AxialLineの格子度 (GridAxiality、以下：GA)、循環度 (Axial Ringiness、以下:AR) と分節度 (AxialArticuration、以下:AA) の 3 評価指標を用い、各対象地区の道路網を解析した。街路網のグ ラフにおけるリンク数とアイランド数という基本的な要素で構成さ れた 3 評価指標の意味及びその式を表 4 に示す。

解析結果 (表 3 の右闌に示寸) をみると、寄与範囲の「 $200 \mathrm{~m} 」 の 「$ 類 型 I」により、3 指標の平均值は GA の 0.20、ARの 0.17、AA の 0.29 で、他の類型に比べて最も低い值となった。つまり、10. 卯辰山麓の ような山間部に立地し、折れ曲がった道で構成されている地区にお いては、不連続の道や不整形な街区が多く、地区全体の循環性が非 常に低いと言える。よって、周辺エリアの計画道路網がそれらの重 伝建地区の道路網の形態を補完し合う場合が多いことから、200m か

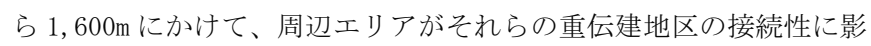
響しや寸い。特に、200m の近隣エリアがそれらの重伝建地区に与え ている影響が顕著であることが示された。それに対して、寄与範囲 が「1,000m」となった「類型IV」に関して、3 評価指標の平均值は、 他の類型に比べてかなり大きくなっていることから、街路網が格子 状の形に近似し、その循環性が優れている重伝建地区ほど、周辺エ アリが地区の接続性に与えている影響は安定しており、影響の寄与 範囲が比較的広くなる傾向が見られた。また、「類型 II」（寄与範囲 の $400 \mathrm{~m}$ ) と「類型III」（寄与範囲の $600 \mathrm{~m}$ ) の地区から見ると、両類 型の GA の平均値が近いが、AR の平均值が小さくなる重伝建地区ほど、 周辺エリアが地区の接続性に与える影響の寄与範囲は比較的広くな る傾向がある。

\section{5. おわりに}

本研究では、街路空間の接続性の観点から、歴史的地区の街路網 と周辺道路との空間的関係性について定量的に把握することを試み た。40の重伝建地区を対象とした解析結果から、周辺地区が重伝建 地区の接続性に与えている影響の特徴を次のようにまとめることが できる。まず、地区と隣接している $200 \mathrm{~m}$ と $400 \mathrm{~m}$ 範囲のエリアは多 くの地区において、その接続性に対してプラスの影響を与えている ことが分かった。次に、周辺エリアの範囲を広くしながら、周辺地 区からのプラスの影響が弱くなり、マイナスの影響を受けている重 伝建地区の数も増える傾向にある。さらに、周辺エリアが重伝建地 区の接続性に及ぼしている影響の寄与範囲に関して、重伝建地区と 近隣している街路空間は、地区内の接続性に与えている影響は比較 的顕著であるが、1,200m 以上になると、街路空間は重伝建地区の接 続性にあまり寄与していないことが判明された。加えて、AxiaLine の形態的指標を用い、各重伝建地区内の街路網の構成特性と寄与範 囲の特徴を把握することができた。

\section{謝辞}

本研究の一部は、科学研究費助成金、基盤研究 (A) (研究者番号 : 70222148、研究代表者：出口敦）の助成を受けており、ここで謝意 を表す。

\section{表 4 道路ネットワークの形態に関する評価指標}

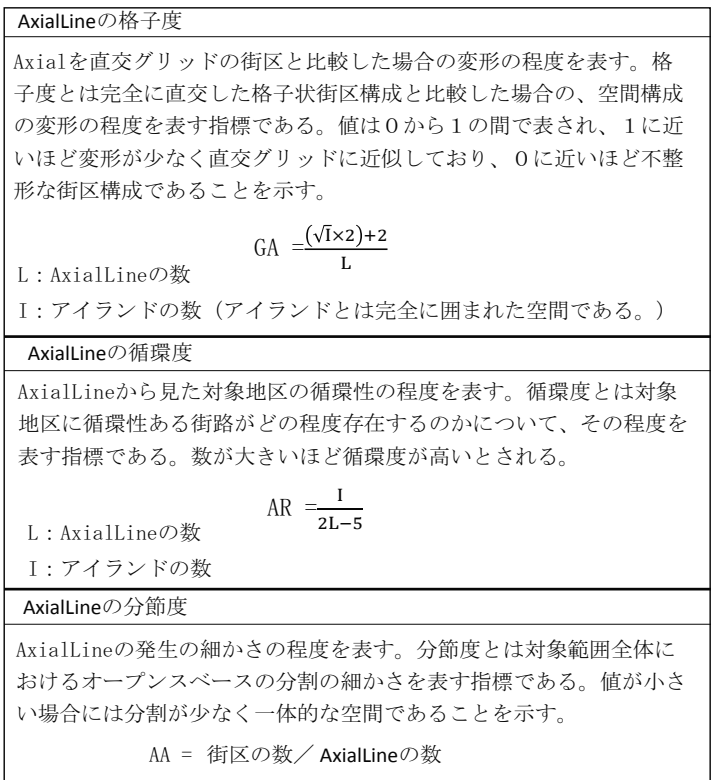

注

注 1) 本研究では, 領域範囲において, “ある街路空間がどれだけ多くの街路と 連接しているか”によって, 各街路の接続関係の強さを表現し, “接続性” として定義した。

注 2) 参考文献 23 の論述により、本研究で都市道路全体を解析するため、局所 のコンベックススペースのサイズが全体のバランスと比較すると小さくすぎ る場合がある。また、Convex Analysisで視覚情報が久落するため、Axial Analysisの方が Convex Analysis より都市空間の分析には適している。

注 3) 参考文献 13 のSS 理論により、凸空間 (コンベックススペース) は都市空 間における可視領域の最小単位として定義された。よって、空間全体を「The least set of the fattest space」の原則により凸空間に分割する。

注 4) 本研究の場合では、研究対象の数や解析範囲などを考慮し、スシンタック ス理論の基本概念に基づき、凸空間を貫く軸線による古典的な作成方法を中 心にして、基本的なAxial Map（軸線マップ）を作成した。さらに、既往研 究（参考文献 $24 、 25 ）$ を参考し、解析ソフトであるDepthmap を用い、軸線マッ プにおける余分な軸線を削り落とした最少軸線によるAxial Map を作成した。

注 5) 本研究において、200m 〜 1600m 範囲の拡大に伴い、周辺エリアが対象地区の 接続性に与える影響で、地区内の Int. V 平均値の増減は異なっている。この場合、 通常の寄与率公式で各範囲区間が全体の変化に寄与した程度を計算する際、寄 与率は極めて意味のわかりにくい数字になって、全体の変化構造を解釈し難く なるという久点がある。故に、本研究で、橋本勝氏（参考文献 16）によって提 唱された修正寄与率を用い、増減の絶対值和を分母としたことで、全体の変化 構造の類似性・相違性を直観的に示す。

\section{参考文献}

1）中村遥子・黒田乃生 : 伝統的建造物群保存地区における街路舗装の現状と課 題 日本建築学会計画系論文集, 第 657 号, pp. $2729 \sim 2736,2010.11$

2) 谷英紀・松本直司・青木一郎・横山太郎 : 美濃加茂市中山道太田宿における 景観構成要素と街路景観の魅力の関係, 伝統的街路景観の魅力に関する研究 その 1 日本建築学会大会学術講演梗概集， E-1, pp707 708, 2012.9

3) 岩崎直子 - 山本明 - 河恵義之 · 土久菜穂：重要伝統的建造物群保存地区 における街路景観に関する調查研究 日本建築学会大会学術講演梗概集, E-1, pp839 840, 2001.9

4) 北山めぐみ・藤木庸介 ・ 藤井将功 ・藤原佑樹 - 平田隆行 : 名古屋市町並夕地 区における歴史的町並みの保全実態その 1 日本建築学会東海支部研究報告 書, 第 49 号, pp. $605 \sim 608,2011.2$

5) 井上智映子 - 菊池成朋 - 天満類子 : 町並み保存整備事業と商業の変遷に関す る研究 : 筑後吉井伝建地区を対象として 日本建築学会大会学術講演梗概集 , E-1, pp1053 1054, 2011.9 
6）和佐田陵亮・大窪健之：名古屋市有松町並み保存地区を対象とした災害 危険性の抽出と対策方針に関する研究 日本建築学会大会学術講演梗概集 , F-1, pp963 964, 2011.8

7) 蘇理萌子・ 川越裕子・渡辺圭太・安井昇・長谷見雄二 : 歴史町並み保存の防 災計画手法の構築に関寸る研究, その 4 奈良井・木曾平沢重伝建地区におけ る冬期防災計画 日本建築学会大会学術講演梗集, A-2, pp21 22, 2008.9

8) 村本健造 ·窪田亜矢・永瀬節治・木口彩・安川千歌子・吉田健一郎：重伝 建地区を中心とする観光徒歩圈の実態把握と分析, 歴史的町並み・佐原に おける回遊性向上に関する研究その 6 日本建築学会大会学術講演梗概集 , F-1, pp195 196, 2011.9

9) パンノイナッタポン・窪田亜矢・櫻庭敬子・鈴木亮平・大熊瑞樹 : 観光客 の回遊性を促進する要素に関する分析, 歴史的町並み・佐原における回遊性 向上に関寸る研究その 1 日本建築学会大会学術講演梗概集, F-1, pp557〜 $558,2010.9$

10）荒屋亮・竹下輝和・池添昌幸 : スペースシンタックス理論に基づく市街 地オープンスペースの特性評価 日本建築学会計画系論文集, 第 589 号, pp. $153 \sim 160,2005.3$

11）太田圭一・郷田桃代：スペース・シンクタックスを用いた密集住宅地にお ける外部空間の空間構造に関寸る研究 日本建築学会大会学術講演梗概集 ,F-1, pp. $903 \sim 904,2008.8$

12) 木川剛志・古山正雄: 都市エントロピー係数を用いたと都市形態解析手法; 日本都市計画論文集, N0. 39-3, pp. $823 \sim 828,2004.10$

13) Hillier B, Hanson J(1984) : Social Logic of Space, Cambridge University Press

14) Hillier B(1996): Space is the machine, Cambridge University Press

15) Hillier B(2007):A Theory of the City as Object, Proceedings, 4th International Space Syntax Symposium

16) 橋本勝: 修正寄与率についての一試論; 經濟論叢, NO. 139, pp. $363 \sim 376$, 1983.4
17) Turner A, Penn A.: Making Isovists Syntactic: Isovist Integration Analysis, in Proceedings of the 2nd International Symposium on Space Syntax, Universidade de Brasilia, Brazil, 1999.

18) Turn,A.: Depthmap: a program to perform visibility graph analysis, in Proceedings of the 3rd International Symposium on Space Syntax, Georgia Institute of Technology, Atlanta, Georgia, 2001.

19）佐藤貴広・郷田桃代・稲坂晃義 : 都市における細街路空間の可視領域に 関する研究：神楽坂を事例として 日本建築学会大会学術講演梗概集, $\mathrm{E}-1, \mathrm{pp} 789 \sim 790,2011.9$

20) 永家 忠司・外尾一則・猪八重拓郎：防犯環境設計における監視性、領域 性の特性評価及び犯罪不安の関連について：スペースシンタックス理論 におけるアクシャルラインとイソビスタを用いて 日本都市計画論文集, Vol. 42, pp. $505 \sim 510$, 2007. 10

21) Yasemin,G.: Analyzing visibility structures in Turkish domestic spaces, in Proceedings of the 6th International Symposium on Space Syntax, Istanbul Technical University, Istanbul, Turkey, 2007.

22) Takashi T, Yuto T, Tatsuya K.: View and viewed analysis, in Proceedings of the 8th International Symposium on Space Syntax, Pontificia Universidad Católica de Chile, Santiago, Chile, 2012.

23）木川剛志・古山正雄 : スペース・シンタックス理論による空間位相構成の 抽出とその比較に関寸る研究, 京都における町家と露地の解析とその比較を 事例として 日本建筑学会計画系論文集, 第 597 号, pp. 9 〜 14, 2005.11

24) Turner A, Doxa M, O'Sullivan D, Penn A.: From isovists to visibility graphs: a methodology for the analysis of architectural space, Environment and Planning B, 28, pp. 103-121, 2001.

25) Turner A, Penn A, Hillier B.: An algorithmic definition of the axial map, Environment and Planning B, 32, pp. 425-444, 2005.

26）兼田敏之・メジアニリム・太田明 : 都市空間の分析概念としてのスペース・ シンタックス理論, シミュレーションによる都市設計を視程に 設計工学, 第 12 号, pp. $559 \sim 565,2012.12$ 


\title{
A STUDY ON THE TOPOLOGICAL CONNECTIVITY OF PRESERVATION DISTRICTS FOR GROUPS OF TRADITIONAL BUILDINGS BY USING THE AXIAL MAP
}

\author{
Ze LIU* and Shichen $Z H A O^{* *}$ \\ * Grad. Stud., Graduate School of Human-Environment Studies, Kyushu Univ., M. Env. \\ ** Assoc. Prof., Faculty of Human-Environment Studies, Kyushu Univ., Dr. Eng.
}

Since the establishment of regulation on Preservation Districts for Groups of Traditional Buildings in 1975, many Japanese cities have been making effort into the preservation of historic Districts. As city's cultural heritage and tourist attraction, the historic Districts is significantly meaningful for creating urban landscape as well as inheriting local characteristics. However, because of inadequate understanding of spatial characteristics, people always focus on the preservation inside historic Districts during local development planning, and neglect the effect on historic Districts which the surrounding area may cause. As the surrounding areas were overdeveloped in some cities, the internal environments of historic Districts are affected negatively, or even destroyed. In order to solve the contradiction between historic Districts preservation and urban development, it's necessary to study the spatial relationship between historic Districts and its surrounding area. In this research, we selected 40 Preservation Districts for Groups of Traditional Buildings in Japanese urban area as objects. From the perspective of Space connectivity, we discussed the spatial relationship between Preservation Districts and surrounding urban roads network, and quantitatively analyzed the surrounding area which would affect the space connectivity of Preservation Districts significantly.

We firstly analyzed the space connectivity of Preservation Districts within itself as well as a surrounding area ranging 2,000 meters by using the Space Syntax Theory. From comparison of connectivity indexes in these two conditions, we found that the surrounding urban area had a significant effect on the space connectivity of Preservation Districts. Meanwhile, the degrees of effect were various due to different types of Preservation Districts. Secondly, we divided the roads in the 2000m-range surrounding area into 5 levels based on the values of space connectivity. By calculating the weights of each road in the Preservation Districts among the total, we analyzed the connective relationship between Preservation Districts and surrounding area. And it turned out that we could divided the 40 objective Preservation Districts into 5 types, from 'Central Type' to 'Discrete Type'. Moreover, we qualitatively studied the characteristics of each type of Preservation Districts based on their developing background and the structure of road network.

After understanding the spatial relationship between Preservation Districts and surrounding area as a whole, we divided the surrounding area of Preservation Districts into a series of ranges from 200 to 1,600 meters by equal value, and quantitatively analyzed the characteristics of its effect on the space connectivity of Preservation Districts as the surrounding area ranges increased. By calculating the connectivity indexes of each range, we found that the road network in the surrounding areas ranging from 200 to 400 meters had positive effects on the space connectivity of Preservation Districts. Moreover, the effects of surrounding areas were uneven and became negative. By analyzing the contribution ratio of connectivity in each range, we found that the surrounding areas ranging from 0 to 200 meters as well as from 200 to 400 meters affected the space connectivity of Preservation Districts most. On the contrary, the surrounding areas ranging more than 1,200 meters had almost no effects. Based on the characteristics of space connectivity and the main ranges of effect, we classified objective areas into 4 types by clustering. Three indexes of 'Grid Axiality', 'Axial Ringiness' and 'Axial Articulation' were considered to analyze the road network of each Preservation Districts type. The cause of each type was studied from the perspective of road structure.

Based on the results, we believed that the range of effect on the space connectivity of Preservation Districts should be considered during road maintenance, so as to avoid the conflicts between urban traffic improvement and the prevention of historical environment as well as road structure. 